\title{
Dietary nutrient composition affects digestible energy utilisation for growth: a study on Nile tilapia (Oreochromis niloticus) and a literature comparison across fish species
}

\author{
J. W. Schrama ${ }^{1}$, S. Saravanan ${ }^{1}$, I. Geurden ${ }^{2}$, L. T. N. Heinsbroek ${ }^{1}$, S. J. Kaushik ${ }^{2}$ and J. A. J. Verreth ${ }^{1}$ \\ ${ }^{1}$ Aquaculture and Fisheries Group, Wageningen Institute of Animal Sciences (WIAS), Wageningen University, PO Box 338, \\ 6700 AH Wageningen, The Netherlands \\ ${ }^{2}$ INRA, UR 1067, Nutrition, Metabolism and Aquaculture (NuMeA), Pôle d'Hydrobiologie INRA, F-64310 St Pée-sur-Nivelle, \\ France
}

(Submitted 3 June 2011 - Final revision received 15 September 2011 - Accepted 16 September 2011 - First published online 18 October 2011)

\section{Abstract}

The effect of the type of non-protein energy (NPE) on energy utilisation in Nile tilapia was studied, focusing on digestible energy utilisation for growth $\left(k_{\mathrm{gDE}}\right)$. Furthermore, literature data on $k_{\mathrm{gDE}}$ across fish species were analysed in order to evaluate the effect of dietary macronutrient composition. A total of twelve groups of fish were assigned in a $2 \times 2$ factorial design: two diets ('fat' $v$. 'starch') and two feeding levels ('low' $v$. 'high'). In the 'fat'-diet, $125 \mathrm{~g}$ fish oil and in the 'starch'-diet $300 \mathrm{~g}$ maize starch were added to $875 \mathrm{~g}$ of an identical basal mixture. Fish were fed restrictively one of two ration levels ('low' or 'high') for estimating $k_{\mathrm{gDE}}$. Nutrient digestibility, N and energy balances were measured. For estimating $k_{\mathrm{gDE}}$, data of the present study were combined with previous data of Nile tilapia fed similar diets to satiation. The type of NPE affected $k_{\mathrm{gDE}}(0.561$ and 0.663 with the 'starch' and 'fat'-diets, respectively; $P<0.001)$. Across fish species, literature values of $k_{\mathrm{gDE}}$ range from 0.31 to $0 \cdot 82$. Variability in $k_{\mathrm{gDE}}$ was related to dietary macronutrient composition, the trophic level of the fish species and the composition of growth (fat:protein gain ratio). The across-species comparison suggested that the relationships of $k_{\mathrm{gDE}}$ with trophic level and with growth composition were predominantly induced by dietary macronutrient composition. Reported $k_{\mathrm{gDE}}$ values increased linearly with increasing dietary fat content and decreasing dietary carbohydrate content. In contrast, $k_{\mathrm{gDE}}$ related curvilinearly to dietary crude protein content. In conclusion, energy utilisation for growth is influenced by dietary macronutrient composition.

Key words: Nile tilapia: Digestible energy: Dietary nutrient composition: Energy metabolism

Fish feeds will have to further diversify ingredient composition due to the limited availability of wild fishery-derived fishmeal and fish oil as dietary protein and lipid sources ${ }^{(1)}$. This diversification is already reflected by the substantial amount of ingredients from oilseeds, pulses and cereals in fish $\operatorname{diets}^{(2-5)}$, which increases the variability in dietary nutrient composition. Inclusion of plant ingredients as a protein source inevitably increases the dietary carbohydrate content. Digestible carbohydrates (i.e. starch) constitute a partial alternative for the digestible energy (DE) supplied by fish oil or vegetable oils in diets, especially for species such as tilapia.

An adequate formulation of animal feed in terms of energy supply requires information on (1) nutrient digestibility of ingredients, (2) energy requirements for maintenance and
(3) utilisation efficiency of DE or metabolisable energy (ME) for growth (respectively, $k_{\mathrm{gDE}}$ and $k_{\mathrm{gME}}$ ). Most energy evaluation systems for farm animals, which have a net energy approach, take into account dietary macronutrient composition-induced differences in energy utilisation efficiency $\left(k_{\mathrm{gDE}}\right.$ or $\left.k_{\mathrm{gME}}\right)$ as seen in pigs ${ }^{(6,7)}$. For instance, in the net energy evaluation system for the Dutch pig, the utilisation efficiency of DE for growth is different between digestible protein, digestible fat and digestible starch, being, respectively, $0.46,0.92$ and $0.77^{(8)}$. In general, energy evaluation in fishfeed formulation is based on the DE of feeds/ingredients and thus does not consider differences in $k_{\mathrm{gDE}}$ induced by dietary macronutrient composition.

Abbreviations: BW, body weight; CP, crude protein; DE, digestible energy; $\mathrm{DE}_{\mathrm{m}}$, digestible energy requirements for maintenance; DP, digestible protein FGR, feed:gain ratio; $\mathrm{ME}$, metabolisable energy; $\mathrm{ME}_{\mathrm{m}}$, metabolisable energy requirements for maintenance; $k_{\mathrm{f}}$, energetic efficiency of fat deposition; $k_{\mathrm{gDE}}$, utilisation efficiency of digestible energy for energy gain; $k_{\mathrm{gME}}$, utilisation efficiency of metabolisable energy for energy gain; $k_{\mathrm{p}}$, energetic efficiency of protein retention; NFE, nitrogen-free extract (total dietary carbohydrates); NPE, non-protein energy; RE, retained energy. 
In fish, energy utilisation efficiency for growth has been estimated on either a DE $\left(k_{\mathrm{gDE}}\right)$ or $\mathrm{ME}\left(k_{\mathrm{gME}}\right)$ basis and mostly using diets with relatively high inclusion levels of fishmeal and fish oil, e.g. rainbow trout (Oncorbynchus mykiss $)^{(9,10)}$, Atlantic cod (Gadus morhua) ${ }^{(11)}$, African catfish (Clarias gariepinus) $^{(12)}$, European eel (Anguilla anguilla $)^{(13)}$, white grouper (Epinephelus aeneus) ${ }^{(14,15)}$, gilthead sea bream (Sparus aurata) $^{(14)}$, European sea bass (Dicentrarchus labrax $^{(14,16)}$. Between studies and/or fish species, a large variability in $k_{\mathrm{gDE}}$ (and/or $k_{\mathrm{gME}}$ ) has been present, with values ranging between 0.60 and 0.80 . So far, little attention has been paid to fish nutrition research on the possible causes of this large variability between fish species as well as within a given species between studies. This variation in $k_{\mathrm{gDE}}\left(\mathrm{and} /\right.$ or $k_{\mathrm{gME}}$ ) between studies and fish species can be due to differences in the composition of somatic growth, because the energetic efficiency of protein retention $\left(k_{\mathrm{p}}\right)$ in fish is lower than that of fat deposition $\left(k_{\mathrm{f}}\right)^{(14,17,18)}$. Moreover, the between-study variation in $k_{\mathrm{gDE}}$ can also be induced by differences in dietary nutrient composition as demonstrated, for example, in grass carp (Ctenopharyngodon idella $)^{(19)}$, rainbow trout $\left(O\right.$. mykiss $^{(18,20)}$ and European eel $(A \text {. anguilla })^{(13)}$. However, in these studies, dietary composition varied in crude protein, fat as well as starch (i.e. carbohydrate) content. Information on a one-by-one comparison between dietary fat and starch (i.e. the type of non-protein energy (NPE) fraction) on $k_{\mathrm{gDE}}$ (and $k_{\mathrm{gME}}$ ) in fish is missing.

The present paper examines the hypothesis that a major part of the variability in $k_{\mathrm{gDE}}$ (and $k_{\mathrm{gME}}$ ) between studies/ fish species stems from differences in macronutrient composition between the experimental diets. First, a feeding trial with Nile tilapia (Oreochromis niloticus) assessed the effect of the NPE source (i.e. fat $v$. starch) on energy utilisation $\left(k_{\mathrm{gDE}}\right.$ and $\left.k_{\mathrm{gME}}\right)$. Nile tilapia was chosen here because of its position at a low trophic level, and thereby assumed to be able to digest and metabolise substantial amounts of starch in comparison with fish at higher trophic levels with more carnivorous feeding habits. Second, energy utilisation values from the literature were analysed in an attempt to explain the large variability in $k_{\mathrm{gDE}}$ across studies/fish species with a specific focus on (1) the proximate composition of the experimental diets used for estimating $k_{\mathrm{gDE}}$, (2) the trophic level of the fish species and (3) the composition of growth (i.e. the ratio of fat:protein gain).

\section{Materials and methods}

\section{Fish and housing}

Male Nile tilapia of the Swansea Silver GMT (Genetically Male Tilapia) strain were obtained from a commercial breeder (Til-Aqua International, Velden, The Netherlands). The experiment was conducted in the fish energy metabolism unit of the Aquaculture and Fisheries group of Wageningen University. This unit consists of twelve 200-litre aquaria $(87 \times 58 \times 46 \mathrm{~cm})$, all connected to the same recirculation system (comprising a common water reservoir, a drum filter for solids removal, a trickling filter for gas exchange and nitrification of $\mathrm{NH}_{4}^{+}$and an oxygenating reactor). At the start of the 6-week experimental period, thirty-four fish were stocked per aquarium. Fish were randomly assigned to aquaria and had a mean body weight (BW) of $75.2 \mathrm{~g}$. Initial stocking density was $12 \cdot 8 \mathrm{~kg} / \mathrm{m}^{3}$.

Water flow of each aquarium was kept constant at 7 litres/min (expect for the first week, when water flow was 6 litres/min). The oxygen concentration of the inlet water was increased until nine parts per million by the addition of pure oxygen to ensure that the dissolved oxygen concentration inside the tanks (i.e. outlet water) did not drop below four parts per million. Water quality was kept within the optimal range for tilapia and was measured weekly. Mean water $\mathrm{pH}$, temperature, conductivity, $\mathrm{NH}_{4}{ }^{+}-\mathrm{N}, \mathrm{NO}_{2}{ }^{-}-\mathrm{N}$ and $\mathrm{NO}_{3}{ }^{-}-\mathrm{N}$ were $7 \cdot 0(\mathrm{SD} 0 \cdot 2), 27 \cdot 7(\mathrm{SD} 0 \cdot 2)^{\circ} \mathrm{C}, 3.31$ (SD $0 \cdot 17$ ) $\mathrm{mS} / \mathrm{cm}, 0.0(\mathrm{SD} 0.0) \mathrm{mg} / \mathrm{l}, 0.2(\mathrm{SD} 0 \cdot 1) \mathrm{mg} / \mathrm{l}$ and 168 (SD 45) $\mathrm{mg} / \mathrm{l}$, respectively. Renewal of water in the system was minimal during the whole experimental period. Consequently, $\mathrm{NO}_{3}{ }^{-}-\mathrm{N}$ concentration increased from 100 to $225 \mathrm{mg} / \mathrm{l}$ during the experiment. A $12 \mathrm{~h}$ light $-12 \mathrm{~h}$ dark photoperiod was maintained with daybreak set at 07.00 hours.

The experiment was approved by the Ethical Committee judging Animal Experiments of Wageningen University, The Netherlands, and carried out according to the Dutch law on animal experiments.

\section{Diets and feeding}

Triplicate aquaria were randomly assigned to one of four experimental treatments, which were arranged in a $2 \times 2$ factorial design: two diets ('fat' $v$. 'starch') and two feeding levels ('low' $v$. 'high'). The experimental diets were similar in composition regarding basal ingredients, but differed in the amount of gross energy originating from either fat or starch (Table 1) by exchanging fish oil and gelatinised maize starch. In the 'fat'-diet, $125 \mathrm{~g}$ fish oil was added to $875 \mathrm{~g}$ of a basal ingredient mixture, whereas in the 'starch'-diet, $300 \mathrm{~g}$ maize starch was added to $875 \mathrm{~g}$ of a basal ingredient mixture. The amount of gross energy in $125 \mathrm{~g}$ fish oil is approximately equal to that in $300 \mathrm{~g}$ gelatinised maize starch. Consequently, the ratio of basal ingredients (e.g. premix) and crude protein content to gross energy was similar between the two diets (Table 1). Based on the analysed dietary crude fat and total carbohydrate content (NFE; Table 1), 68 and $23 \%$ of the dietary NPE content originated from crude fat and 32 and $77 \%$ from NFE in the 'fat' and 'starch' diets, respectively. Digestibility was measured by using acid-insoluble ash as an inert marker. Diamol (Diamol GM; Franz Bertram, Hamburg, Germany) was added to both diets in order to increase the marker content of diets and collected faeces. The diets were produced by Research Diet Services (Wijk bij Duurstede, The Netherlands). The ingredients, excluding the oils, were mixed and thereafter hammer-milled through a $1 \mathrm{~mm}$ screen. The diets were processed by extrusion using a Clextral BC 45 laboratory scale twin-screw extruder (Clextral, Firminy, France) with a $3 \mathrm{~mm}$ die, resulting in a sinking pellet of about $3 \mathrm{~mm}$. In the 'starch' diet, all oils and in the 'fat' diet $2.5 \%$ of the $13.5 \%$ oils were added to the mixture before 
Table 1. Ingredient (\%) and analysed chemical composition $(\mathrm{g} / \mathrm{kg}$ on a DM basis) of the experimental diets

\begin{tabular}{|c|c|c|}
\hline & \multicolumn{2}{|c|}{ Diets } \\
\hline & Fat & Starch \\
\hline \multicolumn{3}{|l|}{ Test ingredients } \\
\hline Fish oil ${ }^{\star}$ & $12 \cdot 50$ & - \\
\hline Gelatinised maize starch $\dagger$ & - & $25 \cdot 53$ \\
\hline \multicolumn{3}{|l|}{ Basal ingredients } \\
\hline Soyabean meal & $30 \cdot 00$ & 25.53 \\
\hline Fishmealł & $25 \cdot 00$ & $21 \cdot 27$ \\
\hline Wheat gluten & $15 \cdot 00$ & $12 \cdot 77$ \\
\hline Wheat bran & $9 \cdot 50$ & 8.09 \\
\hline Soya oil & 1.00 & 0.85 \\
\hline Pellet binder (Durabond) & 2.00 & 1.70 \\
\hline Diamol§ & 2.00 & 1.70 \\
\hline $\mathrm{CaCO}_{3}$ & 0.50 & 0.43 \\
\hline $\mathrm{CaPO}_{4}$ & 1.50 & $1 \cdot 28$ \\
\hline Premix\| & 1.00 & 0.85 \\
\hline \multicolumn{3}{|l|}{ Chemical composition } \\
\hline DM & 967 & 946 \\
\hline Crude protein & 518 & 432 \\
\hline Crude fat & 187 & 56 \\
\hline Ash & 98 & 83 \\
\hline NFE & 197 & 429 \\
\hline Starch and sugars & 36 & 279 \\
\hline Gross energy (kJ/g DM) & $22 \cdot 8$ & 19.7 \\
\hline Crude protein/gross energy (mg/kJ) & $22 \cdot 7$ & $22 \cdot 0$ \\
\hline Digestible protein/digestible energy (mg/kJ) & $24 \cdot 0$ & 23.1 \\
\hline
\end{tabular}

NFE, nitrogen-free extract (total dietary carbohydrate content), calculated as DM crude protein - crude fat - ash content.

* Triple Nine Fish oil, Esbjerg, Denmark.

$\dagger$ Merigel 100; Tate \& Lyle, Amylum Europe NV (Aalst, Belgium).

† Fishmeal LT $(90 \%$ blue whiting and $10 \%$ sprat; protein content $72 \%)$; Triple Nine Fish protein.

$\S$ Diamol GM; Franz Bertram, Hamburg, Germany.

I| Mineral and vitamin composition of premix identical to Tran-Duy et al. ${ }^{(21)}$.

extrusion. Following extrusion, the pellets were dried in a tray drier at $70^{\circ} \mathrm{C}$ for $3 \mathrm{~h}$ and thereafter cooled to ambient temperature. After cooling, the 'fat' diet pellets were coated and the remaining part of the oils and all diets were stored at $4^{\circ} \mathrm{C}$. Before feeding, pellets were sieved to remove dust and small particles.

Fish were fed restrictively during the experiment. In order to estimate $k_{\mathrm{gDE}}$ and $k_{\mathrm{gME}}$ and the energy requirements for maintenance $\left(\mathrm{DE}_{\mathrm{m}}\right.$ and $\left.\mathrm{ME}_{\mathrm{m}}\right)$, two feeding levels were applied: the 'low' level aimed at about 30\% and the 'high' level at about $80 \%$ of the 'satiation' intake. Tran-Duy et al. ${ }^{(21)}$ found an apparent satiation feed intake of $16.0 \mathrm{~g} / \mathrm{kg}^{0-8} \mathrm{BW}$ per $\mathrm{d}$ in 50-160 g Nile tilapia fed comparable diets. Therefore, for the 'starch'-diet, feed ration was set at 6.0 and $13.0 \mathrm{~g} / \mathrm{kg}^{0.8} \mathrm{BW}$ per $\mathrm{d}$ at the 'low' and 'high' feeding levels, respectively. The created contrast between the 'fat' and 'starch' diets resulted in a difference in the nutrient (e.g. protein, energy) concentration between the diets (Table 1). In order to provide the same amount of energy and protein, fish were fed the same amount of basal ingredients at both diets. Therefore, for the 'fat'-diet, the amount of feed ration was set at $5 \cdot 1$ and $11 \cdot 1 \mathrm{~g} / \mathrm{kg}^{0-8} \mathrm{BW}$ per $\mathrm{d}$ for the 'low' and 'high' feeding levels, respectively.

Fish were hand fed once per day. The feeding period started at exactly 13.00 hours and fish were given $1 \mathrm{~h}$ to consume their daily ration. During this feeding period, feed was gradually given (at $2-5$ min intervals) and was adjusted to the demand of the fish, in order to minimise feed spillage. The daily feeding ratio per aquarium was calculated based on the mean initial fish weight, the feeding level of the treatment (in $\mathrm{g} / \mathrm{kg}^{0.8} \mathrm{BW}$ per $\mathrm{d}$ ) and the expected growth of the fish. The daily growth for the feed ration calculation was estimated from the expected feed:gain ratio (FGR). At the 'high' feeding level, the FGR was assumed to be $1 \cdot 1$ for the prediction of daily growth. By definition, the FGR is dependent on the feeding level, due to the dilution of the amount of feed used for maintenance with increasing feeding level. Since the 'low' feeding level was expected to be slightly above the maintenance requirement, a FGR of 4 was assumed for the prediction of daily growth.

\section{Measurements of nitrogen and energy balances}

At the start and end of the $42 \mathrm{~d}$ experimental period, individual fish weights were measured after anaesthetising fish with tricaine methane sulfonate $(0.2 \mathrm{~g} / \mathrm{l}$ buffered with $0.4 \mathrm{~g}$ sodium bicarbonate/1; MS-222; Crescent Research Chemicals, Phoenix, AZ, USA). From weight measurements, mean initial $\left(\mathrm{BW}_{0}\right)$ and final $\mathrm{BW}\left(\mathrm{BW}_{42}\right)$ and the $\mathrm{CV}$ of $\mathrm{BW}_{42}$ were calculated per tank. Growth rate per metabolic weight unit (in $\mathrm{g} / \mathrm{kg}^{0-8} \mathrm{BW}$ per d) was calculated per tank as $\left(\mathrm{BW}_{42}-\mathrm{BW}_{0}\right) \times 42 / \mathrm{MBW}_{\mathrm{m}}$, with $\mathrm{MBW}_{\mathrm{m}}$ being the mean metabolic BW during the experimental period (in $\mathrm{kg}^{0-8}$ ). From the feed ration, uneaten feed and feed spillage, which were recorded daily, feed intake was calculated and expressed as $\mathrm{g} / \mathrm{kg}^{0-8} \mathrm{BW}$ per $\mathrm{d}$ using $\mathrm{MBW}_{\mathrm{m}}$. Feed spillage was recorded by counting the number of feed pellets trapped in the faeces collectors during the feeding period. The FGR was calculated as feed intake divided by growth (both in $\mathrm{g} / \mathrm{kg}^{0.8} \mathrm{BW}$ per $\mathrm{d}$ ).

A representative sample of each diet was taken and stored at $4^{\circ} \mathrm{C}$. Initial body composition was determined in eighteen fish and final body composition in eight randomly selected fish per tank. Fish were euthanised by an overdose of MS$222(0.8 \mathrm{~g} / \mathrm{l}$ buffered with $1.6 \mathrm{~g}$ sodium bicarbonate/l) and stored at $-20^{\circ} \mathrm{C}$. Faeces were daily collected per aquarium during the last 4 weeks of the experiment, according to the procedure described by Amirkolaie et al. ${ }^{(22)}$ using settling tanks. Daily faecal collection started about $15 \mathrm{~min}$ after the end of the feeding period. Before starting feeding, faeces were collected, stored (daily) at $-20^{\circ} \mathrm{C}$ and pooled per aquarium over the experimental period. Throughout the daily faecal collection period, the bottle trapping faeces was continuously submerged in ice water, to prevent bacterial decay. Before chemical analysis, the sampled fish were cut into small pieces, homogenised by grinding in a mincing machine through a $4.5 \mathrm{~mm}$-screen grinder two times and subsequently freeze-dried. The collected faeces were freezedried. The freeze-dried faeces and the sampled feed were ground using a $1 \mathrm{~mm}$-screen grinder.

Chemical analyses were done in triplicate. DM and ash were determined gravimetrically; $\mathrm{DM}$ after drying at $103^{\circ} \mathrm{C}$ for 4,4 and $24 \mathrm{~h}$ until constant weight, respectively, for feed, freeze-dried faeces and fish samples (ISO 6496, 1983); ash 
after incineration at $550^{\circ} \mathrm{C}$ for $4 \mathrm{~h}$ (ISO 5984,1978). Acidinsoluble ash was measured by dissolving the residue obtained after ash determination in $\mathrm{HCl}$ (ISO 5985, 1981). CP $(\mathrm{N} \times 6.25)$ was determined by the Kjeldahl method (ISO 5983, 1979). Fat was quantified after petroleum-diethyl ether extraction (ISO 6492, 1999). Before fat analysis, feed and faecal samples were hydrolysed by boiling for $1 \mathrm{~h}$ with $3 \mathrm{M}-\mathrm{HCl}$. Energy content was measured by direct combustion in an adiabatic bomb calorimeter (IKA-C-7000; IKA-analysentechnik, Weitersheim, Germany). Starch (including free sugars) was analysed according to the method described by Goelema et al. ${ }^{(23)}$. For feed and faeces, NFE (nitrogen-free extract; i.e. starch + free sugars + NSP) was calculated as $\mathrm{DM}-\mathrm{CP}-$ fat - ash. Apparent digestibility coefficients of nutrients were calculated for each aquarium as in Amirkolaie et al. ${ }^{(22)}$ using acid-insoluble ash as an inert marker.

Energy and $\mathrm{N}$ balance parameters were calculated per aquarium and expressed as, respectively, $\mathrm{kJ} / \mathrm{kg}^{0-8} \mathrm{BW}$ per $\mathrm{d}$ and $\mathrm{mg} / \mathrm{kg}^{0.8} \mathrm{BW}$ per $\mathrm{d}$. $\mathrm{N}$ balance calculations were as follows: $\mathrm{N}$ intake as the product of feed intake and dietary $\mathrm{N}$ content; digestible $\mathrm{N}$ intake as $\mathrm{N}$ intake times the $\mathrm{N}$ digestibility coefficient; retained $\mathrm{N}$ as the difference between the final and initial $\mathrm{N}$ body mass; branchial urinary $\mathrm{N}$ losses as digestible $\mathrm{N}$ intake minus retained $\mathrm{N}$. Energy balance calculations were as follows: energy intake as the product of feed intake and dietary energy content; DE intake as energy intake times the energy digestibility coefficient; branchial urinary energy losses as branchial urinary $\mathrm{N}$ losses times the energy concentration of $\mathrm{NH}_{3}-\mathrm{N}\left(24.9 \mathrm{~kJ} \mathrm{~N} / \mathrm{g}^{(24)}\right.$, assuming that all $\mathrm{N}$ was excreted as $\mathrm{NH}_{3}-\mathrm{N}$ ); ME intake as DE minus branchial urinary energy losses; retained energy (RE) as the difference between the final and initial body energy quantities; heat production as ME minus RE.

Fat retention efficiency was calculated as fat deposited (in $\mathrm{g} / \mathrm{kg}^{0.8} \mathrm{BW}$ per $\mathrm{d}$ ) divided by the digestible fat intake (in $\mathrm{g} /$ $\mathrm{kg}^{0.8}$ BW per d).

\section{Statistical analysis}

The data were analysed using the Statistical Analysis Systems statistical software package version 9.1 (SAS Institute, Cary, NC, USA). The mean value of variables such as BW, feed intake, FGR, body composition, digestibility coefficients, N balance and energy balance of the treatment groups were subjected to two-way ANOVA using the procedure general linear model followed by multiple comparison of means using Tukey's multiple range test. $\mathrm{DE}_{\mathrm{m}}$ and $k_{\mathrm{gDE}}$ were derived from RE and DE intake values using linear regression analyses of the general linear model, and $\mathrm{ME}_{\mathrm{m}}$ and $k_{\mathrm{gME}}$ were estimated from RE and ME intake using the data of the present study. To increase the power of the statistical analysis (i.e. the range of $\mathrm{DE}$ and ME intake), these estimates were also done combining the data of the present study and a previous study on Nile tilapia $^{(21)}$. In that previous study ${ }^{(21)}$, measurements were identical and the contrast in diets was similar (replacing $125 \mathrm{~g}$ fat by $300 \mathrm{~g}$ starch), except that fish were fed to satiation in that study. In all tests, the difference between the treatment groups was considered significant when $P<0 \cdot 05$.
From the literature, a database across fish species was created containing estimates of $k_{\mathrm{gDE}}$ and the proximate composition of the diets on a DM basis used in these studies (energy, CP, fat, ash and NFE). Between literature sources, large variability exists in the way of estimating $k_{\mathrm{gDE}}$ in the mode of expression of data on DE intake and $\mathrm{RE}(\mathrm{kJ} / \mathrm{fish}$ per $\mathrm{d}, \mathrm{kJ} / \mathrm{kg}$ BW per $\mathrm{d}, \mathrm{kJ} / \mathrm{kg}^{0.8} \mathrm{BW}$ per $\mathrm{d}, \mathrm{kJ} / \mathrm{kg}^{0.82} \mathrm{BW}$ per $\mathrm{d}$, etc.). From the data in the original papers, $k_{\mathrm{gDE}}$ were estimated by the linear regression of DE intake on RE expressing data as $\mathrm{kJ} / \mathrm{kg}^{0.8} \mathrm{BW}$ per $\mathrm{d}$. When the data on NFE (i.e. the total carbohydrate fraction) were not reported, this was calculated either as DM - CP - fat - ash or from the gross energy, CP and fat content using $23 \cdot 7,39 \cdot 5$ and $17 \cdot 6 \mathrm{~kJ} / \mathrm{g}$ as the energetic values for $\mathrm{CP}$, fat and carbohydrates, respectively. To classify the fish species in the database, regarding natural feeding behaviour (herbivorous $v$. carnivorous), the trophic level reported in FishBase ${ }^{(25)}$ was added to the database. Spearman's correlation coefficients were calculated between $k_{\mathrm{gDE}}$ and the different parameters (dietary proximate composition and trophic level). Additional regression analyses between $k_{\mathrm{gDE}}$ and these parameters were performed.

\section{Results}

Performance data are shown in Table 2. Averaged over treatments, $4.9 \%$ of the rations were not eaten. This was caused by the presence of uneaten feed during the first 2 weeks of the experiment, especially at the 'starch' diet $(P<0.05)$ and at the 'high' feeding level $(P<0.001)$. As planned with the experimental design, the realised feed intake was affected by both diet $(P<0 \cdot 001)$ and feeding level $(P<0 \cdot 001)$. However, due to the higher level of uneaten feed at the 'starch' diet, the intended difference in feed intake (in $\mathrm{g} / \mathrm{kg}^{0.8} \mathrm{BW}$ per d) was slightly small between the 'starch' and 'fat' diets (Table 2). Consequently, both energy and $\mathrm{N}$ intakes were slightly different between the two diets $(P<0.05$; Table 4$)$. However, growth (in $\mathrm{g} / \mathrm{kg}^{0.8} \mathrm{BW}$ per d) was not different between the diets $(P>0 \cdot 1)$, but increased with the feeding level $(P<0 \cdot 001 ;$ Table 2$)$. The FGR was affected by both dietary energy source and feeding level $(P<0 \cdot 001)$ and tended to be affected by the interaction effect $(P=0.061)$. The highest FGR (1.16) was registered in fish fed the 'starch' diet at the 'low' feeding level.

Final body composition is shown in Table 3. The final protein content of fish was similar between the treatments $(P>0 \cdot 1)$. Fat content was influenced by both dietary energy source and feeding level $(P<0 \cdot 01)$ and tended to be affected by the interaction effect $(P<0 \cdot 10)$. Fish fed the 'fat' diet at the 'high' feeding level had the highest fat content (Table 3). A similar pattern, as observed for the fat content, was present for final DM and energy contents.

Apparent digestibility coefficients of all nutrients were affected by both feeding levels $(P<0 \cdot 05)$ and by the dietary energy source $(P<0 \cdot 01)$ (Table 3$)$. For all nutrients, digestibility was higher at the 'low' feeding level compared with the 'high' feeding level. Except for fat digestibility, the digestibility of all nutrients was higher in fish fed the 'starch' diet than in fish fed the 'fat' diet. The digestibility of fat was highest for 
Table 2. Effect of dietary energy source ('starch' $v$. 'fat') and feeding level ('low' $v$. 'high') on feed intake and growth performance of Nile tilapia (Oreochromis niloticus)

(Mean values with their standard errors)

\begin{tabular}{|c|c|c|c|c|c|c|c|c|}
\hline \multirow[b]{3}{*}{ Feeding level } & \multicolumn{4}{|c|}{ Diet } & \multirow[b]{3}{*}{ SEM $^{*}$} & \multirow{2}{*}{\multicolumn{3}{|c|}{$P$}} \\
\hline & \multicolumn{2}{|c|}{ Fat } & \multicolumn{2}{|c|}{ Starch } & & & & \\
\hline & Low & High & Low & High & & $\mathrm{D}$ & $\mathrm{FL}$ & $\mathrm{D} \times \mathrm{FL}$ \\
\hline Growth period (d) & 42 & 42 & 42 & 42 & - & - & - & - \\
\hline Fish per tank $(n)$ & 34 & 34 & 34 & 34 & - & - & - & - \\
\hline Tanks $(n)$ & 3 & 3 & 3 & 3 & - & - & - & - \\
\hline Survival (\%) & 99 & 100 & 100 & 99 & - & - & - & - \\
\hline Initial BW (g) & $75 \cdot 6$ & $75 \cdot 6$ & 74.5 & 74.9 & 0.73 & 0.246 & 0.859 & 0.770 \\
\hline Final BW (g) & $103 \cdot 4^{\mathrm{a}}$ & $168 \cdot 3^{\mathrm{b}}$ & $101 \cdot 0^{\mathrm{a}}$ & $168 \cdot 1^{\mathrm{b}}$ & $2 \cdot 68$ & 0.638 & $<0.001$ & 0.692 \\
\hline $\mathrm{CV}$ of final BW (\%) & $19 \cdot 7$ & $18 \cdot 1$ & 21.4 & $18 \cdot 9$ & 1.56 & 0.459 & 0.236 & 0.795 \\
\hline Feed intake (g/kg ${ }^{0.8}$ BW per d) & $4 \cdot 5^{\mathrm{a}}$ & $9 \cdot 9^{\mathrm{c}}$ & $5 \cdot 1^{\mathrm{b}}$ & $11 \cdot 0^{\mathrm{C}}$ & 0.16 & 0.001 & $<0.001$ & 0.173 \\
\hline Growth $\left(\mathrm{g} / \mathrm{kg}^{0.8}\right.$ BW per d) & $4 \cdot 6^{\mathrm{a}}$ & $12 \cdot 0^{\mathrm{b}}$ & $4 \cdot 4^{\mathrm{a}}$ & $12 \cdot 1^{\mathrm{b}}$ & 0.22 & 0.904 & $<0.001$ & 0.608 \\
\hline FGR & $0.99^{a}$ & $0.83^{b}$ & $1 \cdot 16^{c}$ & $0 \cdot 91^{a, b}$ & 0.020 & $<0.001$ & $<0.001$ & 0.061 \\
\hline
\end{tabular}

D, main effect of dietary non-protein energy source ('starch' $v$. 'fat'); FL, main effect of 'low' $v$. 'high'; $D \times$ FL, interaction effect between diet and feeding level; BW, body weight; FGR, feed:gain ratio.

a,b,c Mean values with unlike superscript letters within a row were significantly different $(P<0.05)$.

${ }^{*} n 3$ per experimental treatment group.

the 'fat' diet. The digestibility of DM, fat and carbohydrates (i.e. NFE) was influenced by the interaction effect of feed level and dietary energy source. For these nutrients, the difference in digestibility between the 'low' and 'high' feeding levels was higher at the 'fat' diet.

In line with the design of the experiment, all parameters of the $\mathrm{N}$ and energy balances were strongly affected by the feeding level $(P<0 \cdot 001$; Table 4$)$. Due to the higher amount of uneaten feed with the 'starch' diet, the daily $\mathrm{N}$ intake and energy intake were slightly lower for the 'starch' diet $(P<0 \cdot 001)$. However, due to both the higher digestibility of energy and the lower amount of energy loss via urine and branchia, the difference in ME intake between the diets was not significant $(P=0.063)$ and was smaller than the difference in energy intake, $5.5 v .9 \cdot 0 \mathrm{~kJ} / \mathrm{kg}^{0.8} \mathrm{BW}$ per d (Table 4). However, the difference in $\mathrm{RE}$ between fish fed both diets increased compared with the difference in ME intake, $8.5 \mathrm{v}$. $5.5 \mathrm{~kJ} / \mathrm{kg}^{0.8} \mathrm{BW}$ per $\mathrm{d}$. Consequently, RE was significantly affected by dietary NPE source $(P<0 \cdot 05)$. The higher RE for the 'fat' diet compared with the 'starch' diet was caused by a higher fat deposition $(P<0.01$; Table 4). Protein retention (i.e. N retention) was similar for both diets $(P>0 \cdot 1)$. Regarding the fat retention, the effect of dietary energy source was dependent on the feeding level, indicated by the significant interaction effect $(P<0 \cdot 05$; Table 4$)$. At the 'low' feeding level, energy retained as fat was equal between the diets,

Table 3. Effect of dietary energy source ('starch' $v$. 'fat') and feeding level ('low' $v$. 'high') on body composition (on fresh weight basis) and apparent digestibility of nutrients in Nile tilapia (Oreochromis niloticus)

(Mean values with their standard errors)

\begin{tabular}{|c|c|c|c|c|c|c|c|c|}
\hline \multirow[b]{3}{*}{ Feeding level } & \multicolumn{4}{|c|}{ Diet } & \multirow[b]{3}{*}{ SEM $^{*}$} & \multirow{2}{*}{\multicolumn{3}{|c|}{$P$}} \\
\hline & \multicolumn{2}{|c|}{ Fat } & \multicolumn{2}{|c|}{ Starch } & & & & \\
\hline & Low & High & Low & High & & D & $\mathrm{FL}$ & $\mathrm{D} \times \mathrm{FL}$ \\
\hline \multicolumn{9}{|c|}{ Final body composition $\dagger$} \\
\hline DM (g/kg) & $274^{a}$ & $294^{\mathrm{b}}$ & $267^{a}$ & $275^{a}$ & $2 \cdot 8$ & 0.002 & $<0.001$ & 0.073 \\
\hline Protein $(\mathrm{g} / \mathrm{kg})$ & 153 & 149 & 152 & 152 & $1 \cdot 2$ & 0.405 & 0.057 & $0 \cdot 111$ \\
\hline Fat $(\mathrm{g} / \mathrm{kg})$ & $78^{\mathrm{a}}$ & $99^{b}$ & $72^{\mathrm{a}}$ & $79^{\mathrm{a}}$ & $3 \cdot 2$ & 0.003 & 0.002 & 0.070 \\
\hline Ash $(\mathrm{g} / \mathrm{kg})$ & 40 & 39 & 38 & 36 & 0.9 & 0.041 & 0.150 & 0.666 \\
\hline Energy $(\mathrm{kJ} / \mathrm{g})$ & $6 \cdot 5^{\mathrm{a}}$ & $7 \cdot 3^{\mathrm{b}}$ & $6 \cdot 3^{\mathrm{a}}$ & $6 \cdot 7^{\mathrm{a}}$ & 0.11 & 0.009 & $<0.001$ & 0.080 \\
\hline \multicolumn{9}{|c|}{ Apparent digestibility } \\
\hline DM (\%) & $85 \cdot 3^{d}$ & $84 \cdot 0^{\mathrm{a}}$ & $87 \cdot 9^{\mathrm{b}}$ & $87 \cdot 1^{\mathrm{c}}$ & 0.09 & $<0.001$ & $<0.001$ & 0.029 \\
\hline Protein (\%) & $95 \cdot 3^{\mathrm{a}, \mathrm{c}}$ & $95 \cdot 1^{\mathrm{a}}$ & $96 \cdot 0^{\mathrm{b}}$ & $95 \cdot 5^{\mathrm{c}}$ & 0.07 & $<0.001$ & 0.004 & 0.156 \\
\hline Fat $(\%)$ & $98 \cdot 2^{\mathrm{C}}$ & $96 \cdot 4^{\mathrm{a}}$ & $96 \cdot 4^{a}$ & $95 \cdot 8^{\mathrm{b}}$ & 0.08 & $<0.001$ & $<0.001$ & $<0.001$ \\
\hline NFE (\%) & $58.9^{d}$ & $55 \cdot 1^{\mathrm{a}}$ & $83 \cdot 6^{b}$ & $82 \cdot 2^{\mathrm{c}}$ & 0.23 & $<0.001$ & $<0.001$ & $<0.001$ \\
\hline Ash (\%) & $61 \cdot 0^{\mathrm{b}}$ & $59 \cdot 3^{a}$ & $62 \cdot 8^{\mathrm{c}}$ & $62 \cdot 5^{\mathrm{b}, \mathrm{c}}$ & 0.33 & $<0.001$ & 0.018 & 0.069 \\
\hline Energy (\%) & $90 \cdot 8^{\mathrm{b}}$ & $89.4^{\mathrm{a}}$ & $91 \cdot 4^{\mathrm{c}}$ & $90 \cdot 5^{\mathrm{b}}$ & 0.09 & $<0.001$ & $<0.001$ & 0.061 \\
\hline
\end{tabular}

D, main effect of dietary non-protein energy source ('starch' $v$. 'fat'); FL, main effect of 'low' $v$. 'high'; $D \times F L$, interaction effect between diet and feeding level; NFE, nitrogen-free extract (total dietary carbohydrates).

a,b,c,d Mean values with unlike superscript letters within a row were significantly different $(P<0.05)$

* $n 3$ per experimental treatment group.

† Initial body composition (on fresh weight basis) was as follows: DM $294 \mathrm{~g} / \mathrm{kg}$; protein $155 \mathrm{~g} / \mathrm{kg}$; fat $101 \mathrm{~g} / \mathrm{kg}$; ash $34 \mathrm{~g} / \mathrm{kg}$; energy $7.4 \mathrm{~kJ} / \mathrm{g}$. 
Table 4. Effect of dietary energy source ('starch' $v$. 'fat') and feeding level ('low' $v$. 'high') on nitrogen and energy balance of Nile tilapia (Oreochromis niloticus)

(Mean values with their standard errors)

\begin{tabular}{|c|c|c|c|c|c|c|c|c|}
\hline \multirow[b]{3}{*}{ Feeding level } & \multicolumn{4}{|c|}{ Diet } & \multirow[b]{3}{*}{ SEM $^{*}$} & \multirow{2}{*}{\multicolumn{3}{|c|}{$P$}} \\
\hline & \multicolumn{2}{|c|}{ Fat } & \multicolumn{2}{|c|}{ Starch } & & & & \\
\hline & Low & High & Low & High & & D & $\mathrm{FL}$ & $\mathrm{D} \times \mathrm{FL}$ \\
\hline \multicolumn{9}{|l|}{$\mathrm{N}$ balance $\left(\mathrm{mg} / \mathrm{kg}^{0.8} \mathrm{BW}\right.$ per $\left.\mathrm{d}\right)$} \\
\hline $\mathrm{N}$ intake & $361^{a}$ & $797^{\mathrm{c}}$ & $333^{\mathrm{a}}$ & $721^{\mathrm{b}}$ & $10 \cdot 8$ & 0.001 & $<0.001$ & 0.057 \\
\hline Digestible $\mathrm{N}$ intake & $344^{\mathrm{a}}$ & $758^{\mathrm{c}}$ & $319^{\mathrm{a}}$ & $689^{b}$ & $10 \cdot 5$ & 0.002 & $<0.001$ & 0.065 \\
\hline Branchial urinary $\mathrm{N}$ losses & $235^{\mathrm{a}}$ & $481^{\mathrm{c}}$ & $217^{\mathrm{a}}$ & $399^{b}$ & $5 \cdot 4$ & $<0.001$ & $<0.001$ & $<0.001$ \\
\hline Retained N & $109^{\mathrm{a}}$ & $276^{\mathrm{b}}$ & $102^{\mathrm{a}}$ & $289^{\mathrm{b}}$ & 6.6 & 0.631 & $<0.001$ & 0.178 \\
\hline \multicolumn{9}{|l|}{ Energy balance $\left(\mathrm{kJ} / \mathrm{kg}^{0.8} \mathrm{BW}\right.$ per $\left.\mathrm{d}\right)$} \\
\hline Energy intake & $99^{\mathrm{a}}$ & $219^{\mathrm{c}}$ & $95^{\mathrm{a}}$ & $205^{\mathrm{b}}$ & $3 \cdot 1$ & 0.016 & $<0.001$ & 0.157 \\
\hline Digestible energy intake & $90^{\mathrm{a}}$ & $196^{\mathrm{b}}$ & $87^{\mathrm{a}}$ & $186^{\mathrm{b}}$ & $2 \cdot 8$ & 0.036 & $<0.001$ & 0.249 \\
\hline Branchial urinary energy losses & $5 \cdot 8^{\mathrm{a}}$ & $12 \cdot 0^{\mathrm{C}}$ & $5 \cdot 4^{a}$ & $9 \cdot 9^{b}$ & 0.14 & $<0.001$ & $<0.001$ & $<0.001$ \\
\hline Metabolisable energy intake & $84^{\mathrm{a}}$ & $184^{\mathrm{b}}$ & $81^{\mathrm{a}}$ & $176^{\mathrm{b}}$ & $2 \cdot 7$ & 0.063 & $<0.001$ & 0.347 \\
\hline Heat production & $67^{a}$ & $98^{\mathrm{b}}$ & $68^{\mathrm{a}}$ & $102^{\mathrm{b}}$ & 2.9 & 0.419 & $<0.001$ & 0.528 \\
\hline Retained energy & $17^{\mathrm{a}}$ & $86^{\mathrm{b}}$ & $13^{\mathrm{a}}$ & $73^{\mathrm{c}}$ & 2.5 & 0.012 & $<0.001$ & 0.107 \\
\hline Retained energy as fat & $0.8^{\mathrm{a}}$ & $45^{\mathrm{b}}$ & $-2^{a}$ & $30^{c}$ & $2 \cdot 4$ & 0.007 & $<0.001$ & 0.039 \\
\hline Retained energy as protein & $16^{\mathrm{a}}$ & $41^{\mathrm{b}}$ & $15^{\mathrm{a}}$ & $43^{b}$ & 1.0 & 0.631 & $<0.001$ & 0.178 \\
\hline
\end{tabular}

whereas at the high feeding level, energy retained as fat in fish fed the 'starch' diet was 33.3\% lower compared with fish fed the 'fat' diet. The observed pattern in energy retained as fat between the treatments paralleled the pattern in fat retention efficiency (i.e. fat gain as a percentage of digestible fat intake; Fig. 1), which was also affected by the interaction effect of diet and feeding level $(P<0 \cdot 05)$. The difference in fat retention efficiency between the two diets also increased with the feeding level. At the 'high' feeding level, the fat retention efficiency was 67 and 134\% for fish fed the 'fat' and 'starch' diets, respectively. This in combination with the similar protein retention (i.e. retained $\mathrm{N}$, Table 4) indicates that de novo lipogenesis from carbohydrates occurred at the 'starch' diet at the 'high' feeding level.

Within the present study, the linear relationship between DE intake and RE (both expressed as $\mathrm{kJ} / \mathrm{kg}^{0-8} \mathrm{BW}$ per $\mathrm{d}$ ) was

$$
\begin{aligned}
& \mathrm{RE}=-40 \cdot 7(\operatorname{sE} 5 \cdot 00)+0 \cdot 636(\operatorname{sE} 0 \cdot 031) \times \mathrm{DE} \\
& \text { for the 'fat'diet, } \\
& \mathrm{RE}=-37 \cdot 6(\operatorname{sE} 5 \cdot 03)+0 \cdot 586(\operatorname{SE} 0 \cdot 033) \times \mathrm{DE} \\
& \text { for the 'starch' diet }
\end{aligned}
$$

with a combined $R^{2}$ of $98.9 \%$. The linear relationship between ME intake and RE (in $\mathrm{kJ} / \mathrm{kg}^{0.8} \mathrm{BW}$ per $\mathrm{d}$ ) was

$$
\begin{aligned}
& \mathrm{RE}=-40 \cdot 3(\operatorname{sE} 5 \cdot 00)+0.675(\operatorname{SE} 0.033) \times \mathrm{ME} \\
& \text { for the 'fat' diet, } \\
& \mathrm{RE}=-36 \cdot 7(\operatorname{sE} 5 \cdot 01)+0.614(\operatorname{sE} 0.035) \times \mathrm{ME} \\
& \text { for the 'starch' diet, }
\end{aligned}
$$

with a combined $R^{2}$ of $98.9 \%$. Both the estimate of $k_{\mathrm{gDE}}$ and $k_{\mathrm{gME}}$ were numerically higher in tilapia fed the 'fat' diet compared with those fed the 'starch' diet. To increase the power of the statistical analysis (i.e. the range of DE and ME intake),
$k_{\mathrm{gDE}}$ and $k_{\mathrm{gME}}$ were estimated combining the data of the present study and a previous study on Nile tilapia ${ }^{(21)}$ in which fish were fed to apparent satiation. On this combined dataset, the linear relationship between DE intake and $\mathrm{RE}$ (in $\mathrm{kJ} / \mathrm{kg}^{0.8} \mathrm{BW}$ per d) was (Fig. 2)

$$
\begin{aligned}
& \mathrm{RE}=-44.5(\mathrm{SE} 4.98)+0.663(\operatorname{SE} 0.021) \times \mathrm{DE} \\
& \text { for the 'fat' diet, }
\end{aligned}
$$

$$
\mathrm{RE}=-34.7(\mathrm{SE} 5 \cdot 41)+0.561(\mathrm{SE} 0.026) \times \mathrm{DE}
$$$$
\text { for the 'starch' diet, }
$$

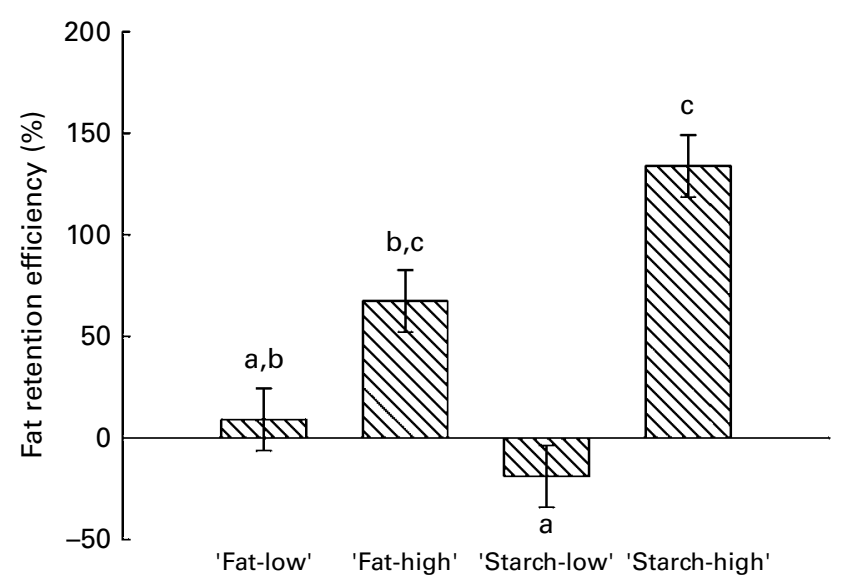

Fig. 1. Effect of dietary energy source ('starch' $v$. 'fat') and feeding level ('low' $v$. 'high') on fat retention efficiency (i.e. fat retention as a percentage of digestible fat intake) of Nile tilapia (Oreochromis niloticus). The $P$ value of the effect of dietary energy source, feeding level and their interaction was $0.244,<0.001$ and 0.015 , respectively. Values are means and standard errors represented by vertical bars. ${ }^{\mathrm{a}, \mathrm{b}, \mathrm{c}}$ Mean values with unlike letters were significantly different $(P<0.05)$. 


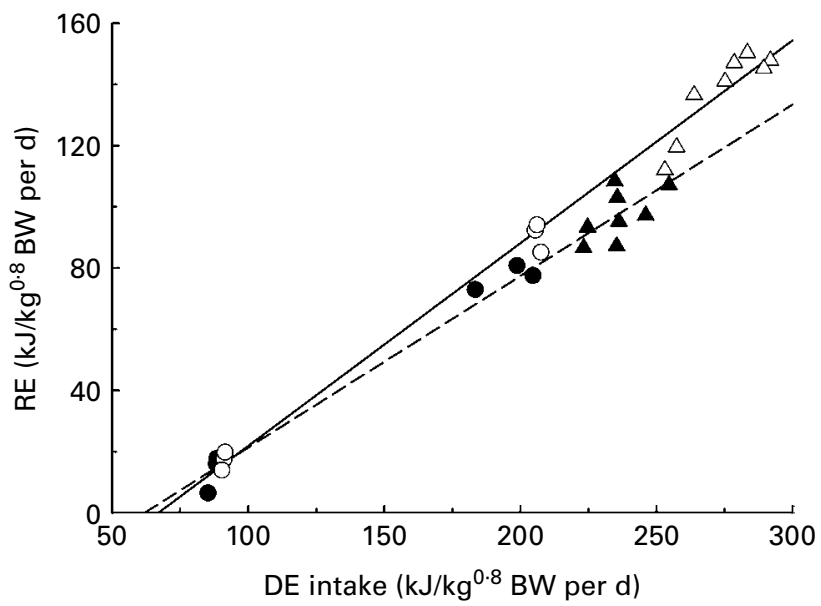

Fig. 2. Relationship between energy retention (RE) and digestible energy (DE) intake in Nile tilapia (Oreochromis niloticus) fed the 'fat' diet $(\mathrm{O}, \Delta)$ and the 'starch' diet $(\boldsymbol{\bullet}, \mathbf{\Lambda})$, combining the data of the present study $(\mathrm{O}, \boldsymbol{\bullet}$, being fish fed restrictively; $n$ 12) and the study of Tran-Duy et al. ${ }^{(21)}(\Delta, \mathbf{\Lambda}$, being fish fed to satiation; $n$ 16). The estimated regression lines at both diets are given in equations (5) and (6). BW, body weight.

with a combined $R^{2}$ of $98.5 \%$. The linear relationship between ME intake and RE (in $\mathrm{kJ} / \mathrm{kg}^{08} \mathrm{BW}$ per $\mathrm{d}$ ) was

$$
\begin{aligned}
& \mathrm{RE}=-42.4(\operatorname{sE} 4.94)+0.689(\operatorname{sE} 0.022) \times \mathrm{ME} \\
& \text { for the 'fat' diet, } \\
& \mathrm{RE}=-32.9(\mathrm{sE} 5.36)+0.579(\operatorname{sE} 0.027) \times \mathrm{ME} \\
& \text { for the 'starch' diet, }
\end{aligned}
$$

with a combined $R^{2}$ of $98.5 \%$. Preliminary analysis showed that estimated intercepts as well as the regression coefficients were not affected when a fixed effect of study was included in the model. Both $k_{\mathrm{gDE}}$ and $k_{\mathrm{gME}}$ were significantly different between the two diets $(P<0 \cdot 001)$, whereas the intercepts of the relationships (equations (5)-(8)) did not differ between the diets $(P>0 \cdot 1) . \mathrm{DE}_{\mathrm{m}}$ were 67 and $62 \mathrm{~kJ} / \mathrm{kg}^{0.8} \mathrm{BW}$ per $\mathrm{d}$ for the 'fat' and 'starch' diets, respectively (derived from equations (4) and (5)). $\mathrm{ME}_{\mathrm{m}}$ were 62 and $56 \mathrm{~kJ} / \mathrm{kg}^{0.8} \mathrm{BW}$ per $\mathrm{d}$ for the 'fat' and 'starch' diets, respectively (derived from equations (7) and (8)). The numerically lower estimated energy requirements for maintenance for the 'starch' diet group compared with the 'fat' diet group were not significant. At both diets, the curvilinear relationships between RE and DE intake as well as between RE and ME intake, described by a quadratic function, were not significant $(P>0 \cdot 1)$.

\section{Discussion}

The present study assessed the effect of the type of NPE source (fat $v$. starch) on energy utilisation in Nile tilapia (O. niloticus). The composition of NPE affected the efficiency of DE utilisation for growth $\left(k_{\mathrm{gDE}}\right.$ (Fig. 2$)$ and $k_{\mathrm{gME}}$ ), but led only to a small numerical difference in the energy requirement for maintenance (both $\mathrm{DE}_{\mathrm{m}}$ and $\mathrm{ME}_{\mathrm{m}}$ ). When fish are fed near the maintenance level, the available DE (and/or ME) is predominantly used for ATP production to sustain vital live processes. Theoretically, the energetic efficiency of ATP production is higher from glucose compared with fat ${ }^{(26)}$ This might be the cause for the 9-10\% numerically lower $\mathrm{DE}_{\mathrm{m}}$ and $\mathrm{ME}_{\mathrm{m}}$ in tilapia fed the 'starch' diet compared with those fed the 'fat' diet. Within fish species, considerable variation in maintenance requirements was present (see $\mathrm{DE}_{\mathrm{m}}$ in Table 5), which was also the case for tilapia. For Nile tilapia, $\mathrm{ME}_{\mathrm{m}}$ was 62 and $56 \mathrm{~kJ} / \mathrm{kg}^{0.8} \mathrm{BW}$ per $\mathrm{d}$ for the 'fat' and 'starch' diets, respectively, in the present study (at $28^{\circ} \mathrm{C}$ ) and $57 \mathrm{~kJ} / \mathrm{kg}^{0.8} \mathrm{BW}$ per $\mathrm{d}$ in the study of Meyer-Burgdorff et al. ${ }^{(27)}$ (at $26^{\circ} \mathrm{C}$ ). In red tilapia ${ }^{(28)}, \mathrm{ME}_{\mathrm{m}}$ was 54 and $77 \mathrm{~kJ} / \mathrm{kg}^{0.8} \mathrm{BW}$ per $\mathrm{d}$ at 21 and $24^{\circ} \mathrm{C}$, respectively. The large variability in maintenance requirements $\left(\mathrm{DE}_{\mathrm{m}}\right.$ and $\left.\mathrm{ME}_{\mathrm{m}}\right)$ within fish species is most probably due to differences in environmental conditions between studies. Environmental conditions such as water temperature $^{(15,28,29)}$, water oxygen concentration ${ }^{(30,31)}$ and stocking density ${ }^{(32,33)}$ have been demonstrated to alter the energy requirements for maintenance in fish. Also between fish species, a large variability in energy requirements for maintenance was present (Table 5). For example, the average $D_{m}$ values for rainbow trout, European sea bass, grass carp and Nile tilapia, given in Table 5, were 35, 42, 67 and $61 \mathrm{~kJ} / \mathrm{kg}^{0.8}$ BW per d, respectively. Next to species-related factors, experimental conditions are likely to contribute to the variability in energy requirements for maintenance between fish species.

So far, little attention has been paid to the possible impact of dietary composition on $\mathrm{DE}_{\mathrm{m}}$ (and $\mathrm{ME}_{\mathrm{m}}$ ). Glencross et al. ${ }^{(34)}$ indicated that $\mathrm{DE}_{\mathrm{m}}$ did not differ between a fishmeal-based diet $v$. diets with 15 or $30 \%$ lupin kernel meal. However, for proper estimation of the effects of dietary composition on $\mathrm{DE}_{\mathrm{m}}$ (and $\mathrm{ME}_{\mathrm{m}}$ ) by the regression of $\mathrm{DE}$ intake on $\mathrm{RE}$, a starvation group as well as groups fed below maintenance should not be included in the dataset. This forces the intercept of the regression lines to be similar, leading to a possible biased estimation of the difference in $\mathrm{DE}_{\mathrm{m}}$ (and $\mathrm{ME}_{\mathrm{m}}$ ). To demonstrate this impact, we recalculated the estimated $\mathrm{DE}_{\mathrm{m}}$ based on the data reported by Glencross et $a l^{\left({ }^{(3)}\right)}$ by the linear regression of $\mathrm{DE}$ on RE. With the inclusion of a common starvation group, $\mathrm{DE}_{\mathrm{m}}$ of trout fed the fishmeal, the $15 \%$ lupin kernel meal or the $30 \%$ lupin kernel meal diet was 38, 42 and $41 \mathrm{~kJ} / \mathrm{kg}^{0.8}$ BW per $\mathrm{d}$, respectively, and excluding the common starvation group, $\mathrm{DE}_{\mathrm{m}}$ was 28,33 and $34 \mathrm{~kJ} / \mathrm{kg}^{0.8}$ BW per $\mathrm{d}$, respectively. With the increasing plant ingredient inclusion in fish feeds, effects of dietary ingredient composition on $\mathrm{DE}_{\mathrm{m}}$ may occur. Since this inclusion can coincide with the introduction of (un)known anti-nutritional factors into the feeds. This aspect deserves further research.

Efficiencies of energy utilisation for RE (i.e. growth) reported in the literature vary regarding the estimation method. First, energetic efficiency can be based on DE $\left(k_{\mathrm{gDE}}\right)$ or $\mathrm{ME}\left(k_{\mathrm{gME}}\right)$. The majority of recent studies on energetic efficiency report $k_{\mathrm{gDE}}$ values, being estimated by the regression of $\mathrm{DE}$ on $\mathrm{RE}$ using comparative carcass analysis together with digestibility measurements. Studies reporting $k_{\mathrm{gDE}}$ are relatively uniform in their approach. In contrast, studies reporting $k_{\mathrm{gME}}$ differ regarding the method of measuring (or calculating) ME intake: (1) by both measuring energy digestibility and estimating the branchial and urinary energy losses through measuring the $\mathrm{N}$ balance (as done in the 
Table 5. Estimates of utilisation efficiencies of digestible energy (DE) and metabolisable energy (ME) for growth (respectively, $k_{\mathrm{g} D E}$ and $k_{\mathrm{gME}}$ ), $\mathrm{DE}$ requirements for maintenance (DE $\mathrm{m}_{\mathrm{m}}$ ) and proximate composition of diets (on a DM basis) used for estimating $k_{\mathrm{gDE}}$ and $k_{\mathrm{gME}}$ in various fish species

\begin{tabular}{|c|c|c|c|c|c|c|c|c|c|c|}
\hline & \multirow[b]{2}{*}{$k_{\mathrm{gME}}$} & \multirow[b]{2}{*}{$k_{\mathrm{gDE}}$} & \multicolumn{5}{|c|}{ Proximate composition (on a DM basis) } & \multirow[b]{2}{*}{ Initial BW (g) } & \multirow[b]{2}{*}{ Trophic level† } & \multirow[b]{2}{*}{$D E_{m}\left(k J / k^{0.8} B W\right.$ per d) } \\
\hline & & & $\mathrm{CP}(\mathrm{g} / \mathrm{kg})$ & Fat $(\mathrm{g} / \mathrm{kg})$ & $\operatorname{NFE}(\mathrm{g} / \mathrm{kg})^{*}$ & Ash $(\mathrm{g} / \mathrm{kg})$ & $\mathrm{GE}(\mathrm{kJ} / \mathrm{g})$ & & & \\
\hline \multicolumn{11}{|l|}{ Fish species } \\
\hline Argyrosomus japonicus ${ }^{(29)}$ & - & 0.60 & 473 & 195 & 238 & 94 & $23 \cdot 1$ & 85 & 4.48 & 47 \\
\hline Salmo salar ${ }^{(42)}$ & 0.82 & 0.80 & 542 & 305 & 59 & 95 & $25 \cdot 1$ & 95 & 4.43 & 32 \\
\hline Oncorhynchus mykiss ${ }^{(34)}$ & - & $0.75 \ddagger(0.75)$ & 483 & 210 & $59 \S$ & 109 & $21.0 \S$ & 96 & 4.42 & $38 \ddagger(41)$ \\
\hline O. mykiss ${ }^{(34)}$ & - & $0.70 \ddagger(0.75)$ & 479 & 215 & $121 \S$ & 98 & $22.4 \S$ & 96 & 4.42 & $42 \ddagger(41)$ \\
\hline O. mykiss ${ }^{(34)}$ & - & $0.75 \ddagger(0.75)$ & 476 & 231 & $170 \S$ & 89 & $23.9 \S$ & 96 & 4.42 & $41 \ddagger(41)$ \\
\hline O. mykiss ${ }^{(10)}$ & 0.63 & $0.62 \ddagger(-)$ & 435 & 235 & 239 & 91 & 24.2 & 160 & 4.42 & 20 \\
\hline O. mykiss ${ }^{(30)}$ & - & 0.62 & 507 & 186 & 209 & 98 & $23 \cdot 1$ & 55 & 4.42 & 44 \\
\hline O. mykiss ${ }^{(9)}$ & 0.61 & $0.55 \ddagger(-)$ & 518 & 269 & 136 & 77 & $25 \cdot 2$ & 13 & 4.42 & 16 \\
\hline O. mykiss ${ }^{(36)} \|$ & - & $0.69 \ddagger(0.76)$ & 471 & 216 & $74 \S$ & 51 & $21.4 \S$ & 97 & 4.42 & $45 \ddagger(39)$ \\
\hline O. mykiss ${ }^{(36)} \|$ & - & $0.74 \ddagger(0.76)$ & 501 & 218 & $52 \S$ & 56 & $21.9 \S$ & 96 & 4.42 & $37 \ddagger(39)$ \\
\hline Lates calcarifer $^{(38)}$ & - & 0.61 & 524 & 233 & 120 & 123 & 24.0 & 15 & $4 \cdot 35$ & 46 \\
\hline L. calcarifer ${ }^{(38)}$ & - & 0.76 & 539 & 206 & 131 & 124 & 23.7 & 410 & 4.35 & 35 \\
\hline Seriola lalandi ${ }^{(37)}$ & - & $0.57 \ddagger(0.55)$ & 531 & 111 & 253 & 106 & 21.4 & 225 & 4.07 & $33 \ddagger(54)$ \\
\hline S. Ialandi ${ }^{(37)}$ & - & $0.60 \ddagger(0.55)$ & 531 & 111 & 253 & 106 & $21 \cdot 4$ & 115 & 4.07 & $86 \ddagger(54)$ \\
\hline S. lalandi ${ }^{(37)}$ & - & $0.56 \ddagger(0.55)$ & 512 & 162 & 215 & 111 & $22 \cdot 1$ & 225 & 4.07 & $44 \ddagger(54)$ \\
\hline S. lalandi ${ }^{(37)}$ & - & $0.57 \ddagger(0.55)$ & 512 & 162 & 215 & 111 & $22 \cdot 1$ & 115 & 4.07 & $88 \ddagger(54)$ \\
\hline Epinephelus aeneus $^{(14)}$ & - & 0.69 & 630 & 198 & 0 & 171 & $22 \cdot 6$ & 180 & 4.02 & 34 \\
\hline Dicentrarchus labrax ${ }^{(14)}$ & - & 0.68 & 630 & 198 & 0 & 171 & $22 \cdot 6$ & 78 & 3.79 & 45 \\
\hline D. labrax ${ }^{(16)}$ & - & 0.68 & 604 & 195 & 18 & 183 & 21.5 & 45 & 3.79 & 44 \\
\hline D. labrax ${ }^{(32)}$ & - & 0.67 & 499 & 202 & 205 & 94 & 23.0 & 72 & 3.79 & 43 \\
\hline D. labrax ${ }^{(32)}$ & - & 0.64 & 499 & 202 & 205 & 94 & 23.0 & 72 & 3.79 & 51 \\
\hline D. labrax ${ }^{(35)}$ & - & $0.82 \ddagger(0.83)$ & 453 & 153 & 308 & 86 & $22 \cdot 8$ & 22 & 3.79 & $27 \ddagger(-)$ \\
\hline Gadus morhua ${ }^{(11)}$ & - & 0.78 & 542 & 305 & 58 & 95 & $25 \cdot 1$ & 250 & 3.73 & 42 \\
\hline G. morhua ${ }^{(11)}$ & - & 0.78 & 649 & 161 & 74 & 116 & $22 \cdot 3$ & 250 & 3.73 & 42 \\
\hline Anguilla anguilla ${ }^{(43)}$ & 0.76 & $0.72 \ddagger(-)$ & 487 & 256 & $145 \pi$ & 111 & $24 \cdot 3$ & 45 & 3.53 & $49 \ddagger(-)$ \\
\hline Sparus aurata ${ }^{(14)}$ & - & 0.65 & 630 & 198 & 0 & 171 & $22 \cdot 6$ & 95 & 3.26 & 48 \\
\hline Pangasianodon hypophthalmus ${ }^{(39)}$ & - & 0.55 & 352 & 113 & 461 & 74 & $20 \cdot 9$ & 40 & $3 \cdot 12$ & 38 \\
\hline Cyprinus carpio ${ }^{(17)}$ & - & $0.76 \ddagger(-)$ & 449 & 131 & 280 & 140 & $20 \cdot 2$ & 155 & 2.96 & $67 \ddagger(-)$ \\
\hline Ctenopharyngodon idella ${ }^{(19)}$ & 0.63 & $0.50 \ddagger(-)$ & 702 & 42 & $194 \pi$ & 62 & $21 \cdot \overline{7}$ & 14 & 2.00 & $68 \ddagger(-)$ \\
\hline C. idella ${ }^{(19)}$ & 0.60 & $0.47 \ddagger(-)$ & 353 & 21 & 579 ๆ & 47 & $19 \cdot 4$ & 14 & 2.00 & $71 \ddagger(-)$ \\
\hline C. idella ${ }^{(19)}$ & 0.69 & $0.66 \ddagger(-)$ & 495 & 165 & 330 ๆ & 10 & $24 \cdot 1$ & 14 & 2.00 & $49 \ddagger(-)$ \\
\hline C. idella ${ }^{(44)}$ & - & $0.31 \ddagger(-)$ & 358 & 31 & 464 & 147 & $17 \cdot 8$ & 12 & 2.00 & 78 \\
\hline Oreochromis niloticus $^{(27)}$ & 0.67 & $0.62 \ddagger(-)^{\star \star}$ & 401 & 113 & 372 & 114 & 21.9 & 7 & 2.00 & $53(-)^{\star *}$ \\
\hline O. niloticus ${ }^{\text {(present study) }}$ & 0.69 & 0.66 & 518 & 187 & 197 & 98 & $22 \cdot 8$ & 75 & $2 \cdot 00$ & 67 \\
\hline O. niloticus (present study) & 0.58 & 0.56 & 432 & 56 & 429 & 83 & $19 \cdot 7$ & 75 & 2.00 & 62 \\
\hline Correlation coefficient with $k_{\mathrm{gDE}}$ & - & - & 0.31 & 0.66 & -0.60 & 0.07 & 0.52 & 0.38 & 0.46 & - \\
\hline$P$ value correlation coefficient & - & - & 0.072 & 0.001 & 0.001 & 0.698 & 0.001 & 0.024 & 0.006 & - \\
\hline
\end{tabular}

$\mathrm{CP}$, crude protein; NFE, nitrogen-free extract (total dietary carbohydrates); GE, gross energy; BW, body weight.

NFE was calculated as DM - CP - fat - ash content, except for values marked with § or $\uparrow$.

$\dagger$ Trophic level given by FishBase ${ }^{(25)}$.

$\ddagger$ Values of $k_{\mathrm{gDE}}$ and $\mathrm{DE} \mathrm{m}_{\mathrm{m}}$ without being marked with $\ddagger$ are reported in the literature from regression of retained energy on $\mathrm{DE}$ intake both expressed per metabolic $\mathrm{BW}\left(\mathrm{kg}^{0.8}\right)$. Values of $k_{\mathrm{gDE}}$ and $\mathrm{DE} \mathrm{m}_{\mathrm{m}}$ being marked with $\ddagger$ are recalculated from the reported data expressing retained energy and DE intake in $\mathrm{kJ} / \mathrm{kg}^{0.8} \mathrm{BW}$ per d. Values between brackets are original $\mathrm{kgE}_{\mathrm{gD}}$ and $\mathrm{DE}_{\mathrm{m}}$ values reported in the literature.

$\S$ Diets in Glencross et al. ${ }^{(34,36)}$ contained cellulose as the inert diet filler. NFE and GE values from these studies are corrected for the amount of cellulose included in the diets.

II The estimates of $k_{\mathrm{gDE}}$ of the reference diet in Glencross et al. ${ }^{(36)}$ were excluded from the dataset, because this reference group was fully identical to the reference diet in Glencross et al. ${ }^{(34)}$.

II NFE value was calculated from gross energy, $\mathrm{CP}$ and fat content using $23.7,39.5$ and $17.6 \mathrm{~kJ} / \mathrm{g}$ as the energetic values for $\mathrm{CP}$, fat and carbohydrates.

${ }^{* *}$ In the study of Meyer-Burgdorff et al. ${ }^{(27)}$, only the ME values were reported. For the estimation of $k_{\mathrm{gDE}}$ and $\mathrm{DE} \mathrm{m}, \mathrm{DE}$ intake was estimated assuming that branchial urinary energy losses were $6.5 \%$ of the $\mathrm{ME}$ intake. 
present study) or (2) by measurements of heat production of fish by either direct or indirect calorimetry. Since the majority of (recent) reported studies estimated $k_{\mathrm{gDE}}$, we restricted ourselves to comparing the current estimated values in the present study on the basis of $k_{\mathrm{gDE}}$. In Table 5 , an overview of reported values in different fish species is given, in which $k_{\mathrm{gDE}}$ is reported and also studies from which $k_{\mathrm{gDE}}$ could be estimated from the reported data. In the majority of studies reported, $k_{\mathrm{gDE}}$ was estimated by expressing DE and RE per unit of metabolic BW using a power of $0 \cdot 8$, but some studies deviated from this; for example, Carter \& Brafield ${ }^{(19)}$ expressed DE and RE as $\mathrm{kJ} / \mathrm{d}$ per fish and Peres \& OlivaTeles $^{(35)}$ as $\mathrm{kJ} / \mathrm{kg}$ BW per $\mathrm{d}$. Values of $k_{\mathrm{gDE}}$ reported in Table 5 are recalculated all on the basis of $\mathrm{kJ} / \mathrm{kg}^{08} \mathrm{BW}$ per $\mathrm{d}$. The present study assessed the impact of NFE composition on energetic efficiency. Therefore, an analysis of $k_{\mathrm{gDE}}$ in relation to dietary nutrient composition was made over fish species. Several studies ${ }^{(34,36,37)}$ given in Table 5 assessed the impact of ingredient/diet composition on $k_{\mathrm{gDE}}$, but none of them found significant differences in $k_{\mathrm{gDE}}$. Unfortunately, only the pooled $k_{\mathrm{gDE}}$ over diets were given in these studies. For these studies, the original $k_{\mathrm{gDE}}$ for each diet was calculated from the reported data.

The $k_{\mathrm{gDE}}$ values estimated in the present study for Nile tilapia (equations (7) and (8)) are in line with the calculated
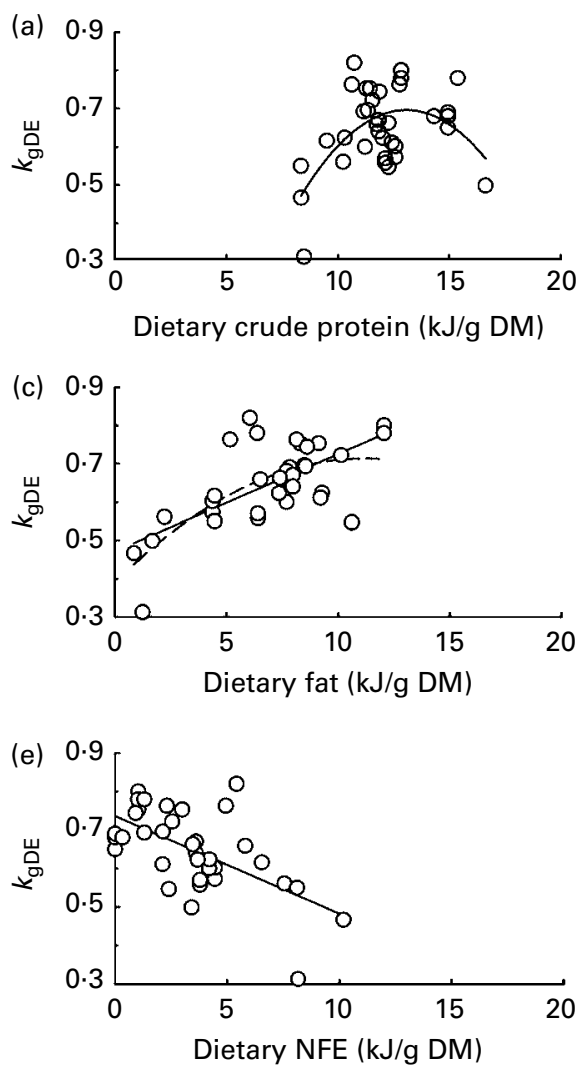

value of $k_{\mathrm{gDE}}$ from the study of Meyer-Burgdorff et al. ${ }^{(27)}$ on Nile tilapia (Table 5). When comparing estimated $k_{\mathrm{gDE}}$ values in different fish species, the large variability is striking, ranging from 0.31 to 0.82 (Table 5). Often one of the reasons suggested for this large variation between fish species is the difference in natural feeding ecology (i.e. carnivorous, omnivorous or herbivorous). The reported studies (Table 5) seem to confirm this, since a positive correlation between $k_{\mathrm{gDE}}$ and the trophic level (obtained from FishBase ${ }^{(25)}$ ) was present ( $r 0 \cdot 46, P<0 \cdot 01$ ). Estimated $k_{\mathrm{gDE}}$ in fish at a lower trophic level (i.e. more herbivorous) are lower than those estimated for fish at a higher trophic level (i.e. more carnivorous) (Fig. 3). However, it should be noted that with changing trophic level, there is also a change in diet composition used in the studies to estimate $k_{\mathrm{gDE}}$. The protein and fat contents of diets used in studies on low-trophic-level fish species are lower than in studies on higher-trophic-level fish species (Table 5), whereas the dietary content of carbohydrates shows the reverse pattern. The proximate composition of diets used in studies to estimate $k_{\mathrm{gDE}}$ correlates with the estimated $k_{\mathrm{gDE}}$ values, except for the dietary ash content (Table 5 and Fig. 3). The residuals of $k_{\mathrm{gDE}}$ of the linear regression of $k_{\mathrm{gDE}}$ on the dietary fat content were not correlated with the trophic level $(r 0.00 ; P>0 \cdot 1)$. This observation, together with the impact of dietary composition within species (Nile tilapia,
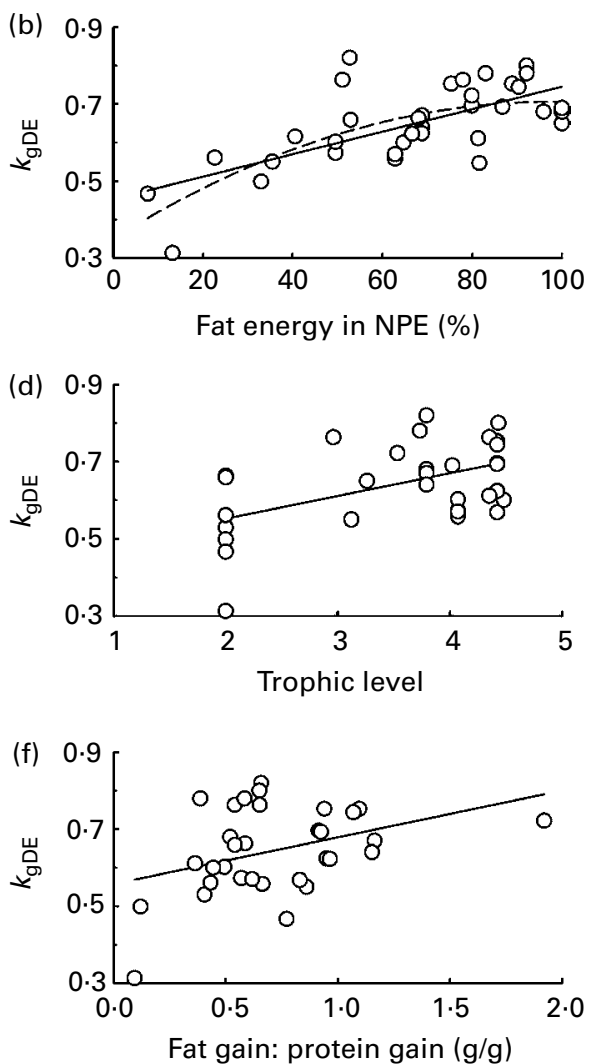

Fig. 3. Relationships between the efficiency of digestible energy utilisation for growth $\left(k_{\mathrm{gDE}}\right)$ reported/derived from the literature in various fish species (given in Table 5) with the following: dietary crude protein content; dietary fat content; dietary total carbohydrate content (nitrogen-free extract; NFE); fat energy as a percentage of dietary non-protein energy (NPE) content; the trophic level of the fish species (derived from FishBase ${ }^{(25)}$ ); the ratio of fat:protein gain (in $\mathrm{g} / \mathrm{g}$ ) at the highest feeding level applied within each treatment group of the respective literature source. Solid lines indicate a significant relationship (either linear or quadratic) with $k_{\mathrm{gDE}}(P<0.05)$ and broken lines indicate a tendency for a significant relationship $(P<0 \cdot 10)$. Equations are presented in Table 6 . 
present study, Fig. 2; trout $\left.{ }^{(18)}\right)$, suggests that the observed positive relationship between $k_{\mathrm{gDE}}$ and the trophic level of fish species is rather diet-induced than species-specific.

Both the experimental data on Nile tilapia and the betweenstudy comparison of $k_{\mathrm{gDE}}$ demonstrate that dietary nutrient composition is an important factor explaining variability in $k_{\mathrm{gDE}}$ values between studies. The between-study comparison showed that both dietary fat and NFE contents were linearly related to $k_{\mathrm{gDE}}(P<0 \cdot 001)$, but for the fat content, the curvilinear function (i.e. quadratic function) tended also to be significant $(P<0 \cdot 10$; Fig. 3 and Table 6$)$. Despite the fact that, theoretically, the formation of ATP is most efficient in animals if glucose is used as the substrate ${ }^{(26)}, k_{\mathrm{gDE}}$ decreases with increasing dietary NFE content (Figs. 2 and 3). This is due to the fact that at higher inclusion levels of NFE, more carbohydrates are used as substrates for de novo fatty acid synthesis. This use of dietary NFE for the synthesis of fatty acids is illustrated by the fat retention efficiency being above $100 \%$ in Nile tilapia fed the 'starch' diet at the 'high' feeding level (Fig. 1). The synthesis of body fat from NFE (synthesis of fatty acids from glucose units) requires more ATP than the synthesis of body fat from fatty acids originating from dietary fat, which causes the decline in $k_{\mathrm{gDE}}$. This phenomenon also explains the increase in $k_{\mathrm{gDE}}$ with increasing dietary fat content, as well as with the increase in the percentage of fat energy within the NPE fraction (Fig. 3 and Table 6). Since dietary fat and NFE contents between studies were strongly negatively correlated $(r-0.74 ; P<0.001)$, the curvilinear trend between $k_{\mathrm{gDE}}$ and dietary fat content is also reflected in a curvilinear trend between $k_{\mathrm{gDE}}$ and the percentage of fat energy within the NPE fraction $(P<0 \cdot 10$; Table 6).

Using the linear equations from the comparison of $k_{\mathrm{gDE}}$ between studies, $k_{\mathrm{gDE}}$ increases by 0.025 units for every increase in the dietary fat content of $1 \mathrm{~kJ} / \mathrm{g}$ DM and decreases by 0.025 units for every increase in the dietary NFE content of $1 \mathrm{~kJ} / \mathrm{g}$ DM (Table 6). Applying these estimates of the effect of fat and NFE contents on $k_{\mathrm{gDE}}$ from Table 6 on the difference in dietary fat and NFE contents in the present study on Nile tilapia (respectively, 131 and $232 \mathrm{~g} / \mathrm{kg}$ DM; Table 1) predicts a difference in the $k_{\mathrm{gDE}}$ of $0 \cdot 129$ and $0 \cdot 102$ units between the 'starch' and 'fat' diets, respectively. This is well in line with the observed difference of 0.102 between the two diets (equations (5) and (6)). The impact of dietary fat content obtained from the between-species comparison of 0.025 units increase in $k_{\mathrm{gDE}}$ per $1 \mathrm{~kJ} / \mathrm{g}$ DM increase in dietary fat content is identical to the estimated impact from a pooled analysis of experiments in rainbow trout ${ }^{(18)}$. This rainbow trout study reported an increase in $k_{\mathrm{gDE}}$ by 0.025 units if dietary fat content increased by $1 \mathrm{~kJ} / \mathrm{g}$ DM.

Next to dietary fat and NFE contents, also the dietary CP content explained part of the variability in $k_{\mathrm{gDE}}$ between studies (Table 5 and Fig. 3). This relationship was curvilinear, i.e. the quadratic component was significant $(P<0 \cdot 01$; Table 6). At both low and high dietary $\mathrm{CP}$ levels, $k_{\mathrm{gDE}}$ was reduced. The reduced $k_{\mathrm{gDE}}$ at low CP levels is most probably due to the fact that low dietary $\mathrm{CP}$ levels coincided with high NFE levels (when the fat level is constant; Table 5), which reduces $k_{\mathrm{gDE}}$ as demonstrated in the present study on Nile tilapia. The reduction in $k_{\mathrm{gDE}}$ at high dietary CP levels is probably caused by the fact that $\mathrm{CP}$ provided in excess to the fish leads to an increased energy demand for ammoniogenesis and for the formation of fatty acids, similarly to the reduced efficiency at high NFE when fat is synthesised from glucose. The analysis of the CP:GE ratio in the diets revealed no relationship with $k_{\mathrm{gDE}}$ $(P>0 \cdot 05$; data not shown). This confirms the aforementioned suggestion that both dietary fat and NFE contents predominantly determine $k_{\mathrm{gDE}}$.

Results of various studies, which assessed the impact of diet composition on the energy utilisation for growth, are not always in line with each other. In Nile tilapia (the present study), grass carp ${ }^{(19)}$, rainbow trout ${ }^{(18,20)}$ and European eel $^{(13)}$, it was shown that diet composition (i.e. differences

Table 6. Linear and quadratic relationships* estimated from the studies reported in Table 5 and depicted in Fig. 3 , explaining the energetic efficiency of digestible energy for growth $\left(k_{\mathrm{gDE}} ; \gamma\right)$ by proximate dietary nutrient composition, trophic level of the fish species and the ratio of fat:protein gain measured at the highest feeding level applied in these studies

\begin{tabular}{|c|c|c|c|}
\hline Equation & $R^{2}(\%)$ & $P$ (linear component) & $P$ (quadratic component) \\
\hline \multicolumn{4}{|l|}{ Dietary crude protein $(X$, in $\mathrm{kJ} / \mathrm{kg} \mathrm{DM})$} \\
\hline$Y=0.44($ SE 0.111$)+0.017($ SE 0.0092$) \times X$ & 9.5 & 0.072 & - \\
\hline$Y=-1.02($ SE 0.431$)+0.262($ SE 0.0708$) \times X-0.010($ SE 0.0029$) \times X^{2}$ & 34.4 & - & 0.002 \\
\hline \multicolumn{4}{|l|}{ Dietary fat $(X$, in $\mathrm{kJ} / \mathrm{kg} \mathrm{DM})$} \\
\hline$Y=0.47(\operatorname{SE~} 0.038)+0.025($ SE 0.0050$) \times X$ & 43.4 & $<0.001$ & - \\
\hline$Y=0.39(\operatorname{SE} 0.056)+0.058(\operatorname{SE~} 0.0178) \times X-0.0026($ SE 0.0014$) \times X^{2}$ & $49 \cdot 2$ & - & 0.067 \\
\hline \multicolumn{4}{|l|}{ Dietary NFE ( $X$, in kJ/kg DM) } \\
\hline$Y=0.74($ SE 0.025$)-0.025($ SE 0.0058$) \times X$ & $36 \cdot 3$ & $<0.001$ & - \\
\hline \multicolumn{4}{|l|}{ Fat energy of dietary non-protein energy $(X$, in \%) } \\
\hline$Y=0.45($ SE 0.039$)+0.0029($ SE 0.0006$) \times X$ & $45 \cdot 8$ & $<0.001$ & - \\
\hline$Y=0.35($ SE 0.065$)+0.007($ SE 0.0023$) \times X-0.037$ (SE 0.019$) \times 10^{-3} \times X^{2}$ & 51.5 & - & 0.062 \\
\hline \multicolumn{4}{|l|}{ Trophic level of fish species $(X)$} \\
\hline$Y=0.46(\mathrm{SE} 0.068)+0.053(\mathrm{SE} 0.0181) \times X$ & $20 \cdot 8$ & 0.006 & - \\
\hline \multicolumn{4}{|l|}{ Ratio of fat:protein gain $(X$, in $\mathrm{g} / \mathrm{g})$} \\
\hline$Y=0.57($ SE 0.042$)+0.113($ SE 0.053$) \times X$ & $13 \cdot 1$ & 0.042 & - \\
\hline
\end{tabular}

NFE, nitrogen-free extract (total dietary carbohydrates).

* Only relationships (both linear and quadratic), which were significant or tended to be significant $(P<0 \cdot 10)$, are given. 
in macronutrient composition by altering ingredient composition) affected the energy utilisation for growth, whereas in other studies on rainbow trout ${ }^{(34,36)}$, yellowtail kingfish ${ }^{(37)}$ and Atlantic $\operatorname{cod}^{(11)}$, no differences between the diets were observed. Except for the Atlantic cod study ${ }^{(11)}$, the absence of a dietary effect on $k_{\mathrm{gDE}}$ is probably due to the relatively small differences in proximate composition of the experimental diets ${ }^{(34,36,37)}$ (Table 5). Moreover, some of these studies, which assessed the impact of the diet on $k_{\mathrm{gDE}}$, included data from a group of fish which were starved ${ }^{(34,36,37)}$. In addition to affecting the estimation of maintenance requirements, inclusion of data from starved fish will also influence the slope of the regression line (i.e. $k_{\mathrm{gDE}}$ ).

The comparison among fish species (Fig. 3 and Table 6) indicates that dietary macronutrient composition can explain up to $52 \%$ of the variation in $k_{\mathrm{gDE}}$, which can be judged as considerable. However, still $48 \%$ of the variation in $k_{\mathrm{gDE}}$ could not be explained. The proportion of explained variability might increase by multiple regression analyses, combining various dietary nutrient contents into the model. However, with the dataset presented in Table 5, this was impossible due to the strong correlation between dietary $\mathrm{CP}$, fat and NFE contents. The proportion of the explained variation in $k_{\mathrm{gDE}}$ would most probably increase if: (1) dietary starch content would be used instead of NFE content and (2) digestible dietary nutrient content were used instead of the crude chemical composition. However, due to the limited amount of data available in the literature, this could not be done. The comparison of $k_{\mathrm{gDE}}$ among fish species (Fig. 3 and Table 6) was made on $k_{\mathrm{gDE}}$ values obtained by the linear regression of $\mathrm{DE}$ on RE. In the present study, the relationship between $\mathrm{DE}$ and RE was best described by a linear relationship. However, in various studies, it has been shown that a curvilinear relationship better describes the relationship between DE and RE, e.g. in rainbow trout ${ }^{(34,36)}$, barramundi ${ }^{(38)}$ and Tra catfish ${ }^{(39)}$. This variability in the relationship between DE intake and RE (linear $v$. curvilinear) may have contributed to the unexplained variability in $k_{\mathrm{gDE}}$ estimated by linear regression (Fig. 3 and Table 6). Another possible factor contributing to the unexplained variability in $k_{\mathrm{gDE}}$ is the difference in the efficiency of protein deposition $\left(k_{\mathrm{p}}\right)$ between fish species. Azevedo et al. ${ }^{(40)}$ compared salmon and trout fed similar diets and found that trout had a $21 \%$ higher $k_{\mathrm{p}}$ compared with salmon. Furthermore, the unexplained variation in $k_{\mathrm{gDE}}$ between studies might be due to the differences in BW of the fish. In barramundi ${ }^{(38)}$ fed the same diet, $k_{\mathrm{gDE}}$ increased with BW of the fish. However, in other studies, it has been found that $\mathrm{BW}$ of the fish did not affect $k_{\mathrm{gDE}}$, e.g. yellowtail kingfish $^{(37)}$. The possible impact of $\mathrm{BW}$ on $k_{\mathrm{gDE}}$ is also suggested by the significant positive correlation between $k_{\mathrm{gDE}}$ among species and the initial BW in the studies reported in Table $5(r 0.38 ; P<0.05)$. However, the residuals of $k_{\mathrm{gDE}}$ of the linear regression of $k_{\mathrm{gDE}}$ on dietary fat content only tended to be correlated with initial BW $(r 0.30 ; P<0 \cdot 10)$, whereas the residuals of the regression of $k_{\mathrm{gDE}}$ on dietary NFE content were not correlated with initial BW $(r 0.23 ; P>0 \cdot 1)$. This suggests that variation in BW between studies had only a minor contribution to the unexplained variation in $k_{\mathrm{gDE}}$.
Moreover, the unexplained variability in $k_{\mathrm{gDE}}$ might be related to differences between fish species in the ratio of fat:protein gain, since the energetic efficiency for protein deposition $\left(k_{\mathrm{p}}\right)$ is lower than that for fat deposition $\left(k_{\mathrm{f}}\right)$ as observed in various fish species ${ }^{(14,17,18)}$. To examine this aspect on the collected dataset from the literature, the ratio of fat:protein gain (in $\mathrm{g} / \mathrm{g}$ ) at the highest feeding level within each treatment (diet) was calculated. As depicted in Fig. 3 and Table 6, this ratio significantly explained part $(13.1 \%)$ of the variation in $k_{\mathrm{gDE}}(P<0 \cdot 05)$, be it less than dietary fat $(>43 \%)$ and NFE (36\%) contents. The residuals of $k_{\mathrm{gDE}}$ of the linear regression $k_{\mathrm{gDE}}$ on dietary fat content were not correlated with the ratio of fat:protein gain $(r 0.05 ; P>0.1)$. In contrast, the residuals of $k_{\mathrm{gDE}}$ of the linear regression of $k_{\mathrm{gDE}}$ on the fat:protein gain ratio were correlated with the dietary fat $(r 0.53$; $P<0.01)$, protein $(r 0.45 ; P<0.01)$ and NFE contents $(r-0.59 ; P<0.001)$. This suggests that the variability in $k_{\mathrm{gDE}}$ between studies as well as between fish species is more likely to be induced by dietary macronutrient composition than by the growth composition. The relationship with growth composition might be due to the impact of dietary macronutrient composition on the ratio of fat:protein gain. In general, a better understanding of the causes of variability in energetic efficiency requires further research.

The finding of the present study that dietary macronutrient composition can have a large impact on the utilisation of DE for growth (both within and between species) has implications for practical diet formulations. In general, energy evaluation in fish-feed formulation is based on the DE of feeds/ingredients. Optimal DE contents of fish feeds are based on the optimal digestible protein (DP):DE ratio. The optimal DP:DE ratio for fish species is either obtained from experimental studies, as, for example, summarised in the National Research Coun$\mathrm{cil}^{(41)}$, or derived from factorial models which describe both energy and protein partitioning over somatic and non-somatic (i.e. maintenance) growth compartments ${ }^{(15,16,38)}$. Using the optimal DP:DE ratio as the basis for diet formulation is valid as long as the proximate composition (i.e. CP, fat and starch content) of the practical feeds is comparable with that of the experimental diets used to estimate/derive the optimal DP:DE ratio for a fish species. However, in light of the expected diversification in ingredients used in fish-feed formulations, also dietary ratios of, for example, starch:fat might vary. Based on the present findings, changes in the dietary NPE composition will alter the $k_{\mathrm{gDE}}$ values of these diets and thus estimations of the optimal DP:DE ratio of these diets. To overcome this impact of changes in dietary composition on the optimal DP:DE ratio, a transition from evaluating ingredients/diets on a DE basis towards an evaluation of net energy may be required in fish-feed formulations, as established in pig nutrition ${ }^{(6,7)}$. Such a net energy evaluation, although expected to be more relevant for herbivorous fish displaying a higher capacity to digest and utilise substantial amounts of starch, is also interesting from a comparative point of view (between fish species and between fish and terrestrial animals).

In conclusion, in Nile tilapia, the energy utilisation for growth depends on the type of NPE source. Exchanging fish 
oil by maize starch $(125 v .300 \mathrm{~g} / \mathrm{kg}$ of feed intake) reduced the DE utilisation for growth $\left(k_{\mathrm{gDE}}\right)$ from 0.663 to 0.561 . Part of the variability in $k_{\mathrm{gDE}}$ across fish species reported in the literature relates to (1) the proximate composition of the experimental diets used for estimating $k_{\mathrm{gDE}}$, (2) the trophic level of the fish species and (3) the composition of growth (i.e. the ratio of fat:protein gain). However, the across-species comparison suggests that variability explained by trophic level and by the composition of growth is predominantly induced by differences in dietary proximate composition. In line with the findings in the present study on Nile tilapia, increasing the dietary fat content increases $k_{\mathrm{gDE}}$ and increasing the dietary carbohydrate content (NFE) decreases $k_{\mathrm{gDE}}$. Opposite to fat and carbohydrate, which are linearly related to $k_{\mathrm{gDE}}$, the dietary CP content is curvilinearly related to $k_{\mathrm{gDE}}$ : both at a 'low' and a 'high' dietary CP contents, $k_{\mathrm{gDE}}$ is reduced.

\section{Acknowledgements}

The present study was funded by the Aquaculture and Fisheries Group of the Department of Animals Sciences, Wageningen University, The Netherlands and was carried out in the aquatic respirometry facilities, which were co-funded by the NWO (Den Haag, The Netherlands, code 805-34.025). Thanks are due to Menno ter Veld and Ep Eding for their technical support in running the experiment and operating the experimental systems. Furthermore, Ronald Booms and Tino Leffering are acknowledged for their support during the chemical analysis. J. W. S. and J. A. J. V. designed the study. J. W. S. performed the data analysis. All authors were involved in the interpretation of the data and preparation of the manuscript. There are no contractual agreements for the presented data, which might cause conflicts of interest.

\section{References}

1. Food and Agriculture Organization (2010) The State of World Fisheries and Aquaculture 2010. Rome: FAO.

2. Gatlin DM, Barrows FT, Brown P, et al. (2007) Expanding the utilization of sustainable plant products in aquafeeds: a review. Aquacult Res 38, 551-579.

3. Glencross BD, Booth M \& Allan GL (2007) A feed is only as good as its ingredients - a review of ingredient evaluation strategies for aquaculture feeds. Aquacult Nutr 13, 17-34.

4. Lim C, Webster CD \& Lee CS (2008) Alternative Protein Sources in Aquaculture Diets. New York: Haworth Press.

5. Tacon AGJ \& Metian M (2008) Global overview on the use of fish meal and fish oil in industrially compound aquafeeds: trends and future prospects. Aquaculture 285, 146-158.

6. Noblet J, Fortune H, Shi XS, et al. (1994) Prediction of net energy value of feeds for growing pigs. J Anim Sci 72, 344-354.

7. Schrama JW, Bosch MW, Verstegen MWA, et al. (1998) The energetic value of nonstarch polysaccharides in relation to physical activity in group-housed, growing pigs. J Anim Sci 76, 3016-3023.

8. Centraal Veevoederbureau (1993) Veevoedertabel (Animal Feedstuffs Table). Lelystad: Centraal Veevoederbureau in Nederland.

9. Azevedo PA, Cho CY, Leeson S, et al. (1998) Effects of feeding level and water temperature on growth, nutrient and energy utilization and waste outputs of rainbow trout (Oncorbynchus mykiss). Aquat Living Resour 11, 227-238.

10. Bureau DP, Hua K \& Cho CY (2006) Effect of feeding level on growth and nutrient deposition in rainbow trout (Oncorbynchus mykiss) growing from 150 to $600 \mathrm{~g}$. Aquacult Res 37, 1090-1098.

11. Hatlen B, Helland SJ \& Grisdale-Helland B (2007) Energy and nitrogen partitioning in $250 \mathrm{~g}$ Atlantic cod (Gadus morbua L.) given graded levels of feed with different protein and lipid content. Aquaculture 270, 167-177.

12. Hogendoorn H (1983) Growth and production of the African catfish, Clarias lazera (D. \& V.). III. Bioenergetic relations of body weight and feeding level. Aquaculture 35, 1-17.

13. Heinsbroek LTN, van Hooff PLA, Swinkels W, et al. (2007) Effects of feed composition on life history developments in feed intake, metabolism, growth and body composition of European eel, Anguilla anguilla. Aquaculture 267, $175-187$.

14. Lupatsch L, Kissil GWM \& Sklan D (2003) Comparison of energy and protein efficiency among three fish species gilthead sea bream (Sparus aurata), European sea bass (Dicentrarchus labrax) and white grouper (Epinephelus aeneus): energy expenditure for protein and lipid deposition. Aquaculture 225, 175-189.

15. Lupatsch I \& Kissil GW (2005) Feed formulations based on energy and protein demands in white grouper (Epinephelus aeneus). Aquaculture 248, 83-95.

16. Lupatsch L, Kissil GWm \& Sklan D (2001) Optimization of feeding regimes for European sea bass Dicentrarchus labrax: a factorial approach. Aquaculture 202, 289-302.

17. Schwarz FJ \& Kirchgessner M (1995) Effects of different diets and levels of feeding on retention and efficiency of utilization of energy and protein by carp (Cyprinus carpio L.). J Appl Ichthyol 11, 363-366.

18. Rodehutscord M \& Pfeffer E (1999) Maintenance requirement for digestible energy and efficiency of utilisation of digestible energy for retention in rainbow trout, Oncorchynchus myskiss. Aquaculture 179, 95-107.

19. Carter CG \& Brafield AE (1991) The bioenergetics of grass carp, Ctenoharyngodon idella (Val.): energy allocation at different planes of nutrition. J Fish Biol 39, 873-887.

20. Glencross B, Hawkins W, Evans D, et al. (2008) Assessing the implications of variability in the digestible protein and energy value of lupin kernel meals when fed to rainbow trout, Oncorhynchus mykiss. Aquaculture 277, 251-262.

21. Tran-Duy A, Smit B, van Dam AA, et al. (2008) Effects of dietary starch and energy levels on maximum feed intake, growth and metabolism of Nile tilapia, Oreochromis niloticus. Aquaculture 277, 213-219.

22. Amirkolaie AK, Verreth JAJ \& Schrama JW (2006) Effect of gelatinization degree and inclusion level of dietary starch on the characteristics of digesta and faeces in Nile tilapia (Oreochromis niloticus (L.)). Aquaculture 260, 194-205.

23. Goelema JO, Spreeuwenberg MAM, Hof G, et al. (1998) Effect of pressure toasting on the rumen degradability and intestinal digestibility of whole and broken peas, lupins and faba beans and a mixture of these feedstuffs. Anim Feed Sci Technol 76, 35-50.

24. Bureau DP, Kaushik SJ \& Cho CY (2002) Bioenergetics. In Fish Nutrition, pp. 1-59 [JE Halver and RW Hardy, editors]. New York: Academic Press.

25. FishBase (2011) http://fishbase.org/ (accessed March 2011).

26. Blaxter K (1989) Energy Metabolism in Animals and Man. Cambridge: Cambridge University Press. 
27. Meyer-Burgdorff KH, Osman MF \& Günther KD (1989) Energy metabolism in Oreochromis niloticus. Aquaculture 79, 283-291.

28. Hepher B, Liao IC, Cheng SH, et al. (1983) Food utilization by red tilapia - effects of diet composition, feeding level and temperature on utilization efficiencies for maintenance and growth. Aquaculture 32, 255-275.

29. Pirozzi I, Booth MA \& Allan GL (2010) Protein and energy utilization and the requirements for maintenance in juvenile mulloway (Argyrosomus japonicus). Fish Physiol Biochem 36, 109-121.

30. Glencross BD (2009) Reduced water oxygen levels affect maximal feed intake, but not protein or energy utilization efficiency of rainbow trout (Oncorbynchus mykiss). Aquacult Nutr 15, 1-8.

31. Tran-Duy A, van Dam AA \& Schrama JW (2011) Feed intake, growth and metabolism of Nile tilapia (Oreochromis niloticus) in relation to dissolved oxygen concentration. Aquacult Res (Epublication ahead of print version 3 May 2011).

32. Lupatsch L, Santos GA, Schrama JW, et al. (2010) Effect of stocking density and feeding level on energy expenditure and stress responsiveness in European sea bass Dicentrarchus labrax. Aquaculture 298, 245-250.

33. Santos GA, Schrama JW, Mamauag REP, et al. (2010) Chronic stress impairs performance, energy metabolism and welfare indicators in European seabass (Dicentrarchus labrax): the combined effects of fish crowding and water quality deterioration. Aquaculture 299, 73-80.

34. Glencross BD, Hawkins W, Evans D, et al. (2008) Evaluation of the influence of Lupinus angustifolius kernel meal on dietary nutrient and energy utilization efficiency by rainbow trout (Oncorbynchus mykiss). Aquacult Nutr 14, 129-138.

35. Peres H \& Oliva-Teles A (2005) Protein and energy metabolism of European seabass (Dicentrarchus labrax) juveniles and estimation of maintenance requirements. Fish Physiol Biochem 31, 23-31.
36. Glencross BD, Hawkins W, Evans D, et al. (2007) Evaluation of the influence of drying process on the nutritional value of lupin protein concentrates when fed to rainbow trout (Oncorbynchus mykiss). Aquaculture 265, 218-229.

37. Booth MA, Allan GL \& Pirozzi I (2010) Estimation of digestible protein and energy requirements of yellowtail kingfish Seiola lalandi using a factorial approach. Aquaculture 307, 247-259.

38. Glencross BD (2008) A factorial growth and feed utilization model for barramundi, Lates calcarifer based on Australian production conditions. Aquacult Nutr 14, 360-373.

39. Glencross B, Hien TTT, Phuong NT, et al. (2010) A factorial approach to defining the energy and protein requirements of Tra catfish, Pangasianodon bupothalalus. Aquacult Nutr 17, e396-e405.

40. Azevedo PA, van Milgen J, Leeson S, et al. (2005) Comparing efficiency of metabolizable energy utilization by rainbow trout (Oncorbynchus mykiss) and Atlantic Salmon (Salmo salar) using factorial and multivariate approaches. J Anim Sci 83, 842-851.

41. National Research Council (1993) Nutrient Requirements of Fish. Washington, DC: National Academy Press.

42. Helland SJ, Hatlen B \& Grisdal-Helland B (2010) Energy, protein and amino acid requirements for maintenance and efficiency of utilization for growth of Atlantic salmon postsmolts determined using increasing ration levels. Aquaculture 305, 150-158.

43. Owen SF, Houlihan DF, Rennie MJ, et al. (1998) Bioenergetics and nitrogen balance of the European eel (Anguilla anguilla) fed at high and low ration levels. Can J Fish Aquat Sci 55, 2365-2375.

44. Cui Y, Chen S \& Wang S (1994) Effect of ration size on the growth and energy budget of the grass carp, Ctenoharyngodon idella Val. Aquaculture 123, 95-107. 